\title{
Advantage of conductive materials on interspecies electron transfer-independent acetoclastic methanogenesis: A critical review
}

\author{
Leilei Xiao $^{\text {a,b,2,*, Eric Lichtfouse }}{ }^{\text {c,d,1, }}$, P. Senthil Kumar ${ }^{\text {ef, }, *}$ \\ ${ }^{a}$ Key Laboratory of Coastal Biology and Biological Resources Utilization, Yantai Institute of Coastal Zone Research, Chinese Academy of Sciences, Yantai 264003, PR \\ China \\ ${ }^{\mathrm{b}}$ CAS Key Laboratory of Coastal Environmental Processes and Ecological Remediation, Yantai Institute of Coastal Zone Research, Chinese Academy of Sciences, Yantai \\ 264003, PR Chine \\ ${ }^{c}$ Aix-Marseille Univ, CNRS, IRD, INRA, Coll France, CEREGE, Avenue Louis Philibert, Aix en Provence 13100, France \\ d State Key Laboratory of Multiphase Flow in Power Engineering, Xi'an Jiaotong University, Xi'an, Shaanxi 710049, PR China \\ ${ }^{\mathrm{e}}$ Department of Chemical Engineering, Sri Sivasubramaniya Nadar College of Engineering, Chennai 603110, India \\ ${ }^{\mathrm{f}}$ Centre of Excellence in Water Research (CEWAR), Sri Sivasubramaniya Nadar College of Engineering, Chennai 603110, India
}

\section{A R T I C L E I N F O}

\section{Keywords:}

Anaerobic digestion

Methane

Biochar

Activated carbon

Magnetite

Direct interspecies electron transfer

\begin{abstract}
A B S T R A C T
Fossil-fuel overuse and global warming are calling for new techniques to provide sustainable fuels. Biomethane can be produced by anaerobic digestion of organic waste, yet microbial mechanisms involved are still debated. Traditionally, reduction of carbon dioxide $\left(\mathrm{CO}_{2}\right)$ to methane $\left(\mathrm{CH}_{4}\right)$ is commonly explained by interspecies electron transfer, i. e., direct interspecies electron transfer (DIET)-based $\mathrm{CO}_{2}$ reduction or mediated interspecies electron transfer (MIET)-based $\mathrm{CO}_{2}$ reduction. For DIET-based $\mathrm{CO}_{2}$ reduction, or DIET-CO $\mathrm{CO}_{2}$ reduction, where electrons are provided by electricigens and transferred to methanogenic archaea to complete $\mathrm{CO}_{2}$ reduction for methane production. Methanogenesis is also executed and facilitated by acetoclastic methanogenesis in the presence of conductive materials, as evidenced recently. Here we compare DIET-CO $\mathrm{C}_{2}$ reduction and acetoclastic methanogenesis mediated by conductive materials. In the past decade, DIET- $\mathrm{CO}_{2}$ reduction is considered as the backbone for methane production strategy in anaerobic engineering digestion. But increasing evidences propose the importance of acetoclastic methanogenesis strengthened by exogenous media. DIET-based $\mathrm{CO}_{2}$ reduction has been extensively reviewed. Herein, we conclude the diverse microbial mechanisms affected by conductive materials to improve potential acetoclastic methanogenesis for the first time. Increasing electron transfer in methanogenic archaea and/or between bacteria and methanogens, microbial immobilization, $\mathrm{pH}$ buffering capacity, providing metal ions, reducing toxicity, regulation of oxidation-reduction potential are detailed reviewed. Possible future application based on acetotrophic methanogens is suggested via conductive materials in anaerobic digestion and natural ecological environment management.
\end{abstract}

\section{Introduction}

Methane is an abundant gaseous hydrocarbon produced by chemical, geological and biological processes. Methane is a both greenhouse gas contributing to global warming and a rather clean and efficient fuel. While emissions of fossil methane increase global warming, production of methane from actual biomass, e.g. organic waste, is considered carbon neutral for the climate (Fig. 1). Biomethane is produced solely by microbial methanogens, which belong to the archaea kingdom, yet precise microbial mechanisms of biomethane production are not fully understood [114,21]. A better knowledge of factors controlling biomethane emission would be useful both to improve industrial biomethane production, and to design techniques of land management that limit methane emission to the atmosphere $[24,79,80,96]$. This manuscript reviews the latest reports on mechanisms of methanogenesis by anaerobic fermentation.

\footnotetext{
* Corresponding authors at: Institute of Coastal Zone Research, 17 Chunhui Road, Laishan District, Yantai, Shandong 264003, PR China (L. Xiao). Department of Chemical Engineering, Sri Sivasubramaniya Nadar College of Engineering, Chennai, 603110 India (Senthil Kumar).

E-mail addresses: 1lxiao@yic.ac.cn (L. Xiao), senthilkumarp@ssn.edu.in (P. Senthil Kumar).

1 ORCID 0000-0002-8535-8073.

2 ORCID 0000-0002-8126-6526.
} 
Methanogenesis is the last step for anaerobic mineralization of organic matter [21]. Biodegradation of biomass to methane is performed by hydrolytic bacteria, acid-producing bacteria, acetogenic bacteria and methanogens [5]. The efficiency of methanogenesis is controlled by syntrophic interactions between bacteria and methanogens, which have complementary metabolisms $[13,39,64,124]$. In particular, bacteria and methanogens share electrons using two mechanisms: transfer of small compounds, e.g. hydrogen/formate, and direct electron transfer $[64,92,121]$. For instance, compounds such as hydrogen and formate act as electron shuttles in a process named interspecies hydrogen/formate transfer (IHT/IFT, [92]). Alternatively, electrons can be transferred directly between electroactive microorganisms and methanogens, named direct interspecies electron transfer (DIET). Electrically conductive pili (e-pili) and proteins are involved in this progress with methanogenic archaea as electron acceptor, yet relative research is still in infancy and the mechanism is still poorly known $[27,64]$ ).

Methane production by anaerobic fermentation can be improved by adding conductive materials, which favor DIET coupled with $\mathrm{CO}_{2}$ reduction, or DIET-based $\mathrm{CO}_{2}$ reduction, or DIET- $\mathrm{CO}_{2}$ reduction. DIET$\mathrm{CO}_{2}$ reduction has been systematically proposed to explain methane production in studies lacking specific experiments allowing to decipher the mechanisms (Tables 1 and 2). This mechanism has been extensively reviewed $[39,64,68,129]$. Yet insights from recent reports point to another mechanism. For instance, Martins et al. [71] found no correlation between increased methane generation and electrical conductivity, suggesting that DIET is involved partly at most. Moreover, DIET has been evidenced unambiguously only in co-cultures of Geobacter with either Methanosarcina or Methanosaeta (Methanothrix) (Table 1; but Geobacter sp. are rarely detected in systems where methane production is enhanced [71,126]). Van Steendam et al. [101] concluded that many investigations lacked direct experimental evidence for the role of DIET in enhancing the performance of anaerobic digestion.

Another insight for an alternative mechanism is the predominance of acetotrophic methanogens to complete acetoclastic methanogenesis, which contribute more that than $70 \%$ of methane during anaerobic digestion $[5,18]$. Interestingly, the main methanogens using DIET-CO reduction for methane generation are still acetotrophic methanogens, i. e., Methanosaeta and Methanosarcina, rather than hydrogenetrophic methanogens. Acetotrophic methanogens is thus suggesting a benefit from conductive materials. Recently, addition of conductive carbon nanotubes and nano-magnetite in pure cultures has favored acetoclastic methanogenesis (Table 1). These materials also accelerate direct acetate dismutation in anaerobic soils and anaerobic sludges [35,37,85,47,120] (Table 2). Similarly, biochar and granular activated carbon facilitate direct acetate dismutation, as firmly evidenced by isotope tracing $[120,122,124]$. Recent advances in methanogenesis through DIET- $\mathrm{CO}_{2}$ reduction via conductive materials are substantially reviewed. Therefore, here we specially focus on the effect of conductive materials on acetotrophic methanogens and potential acetoclastic methanogenesis.

\section{Methanogens and mechanisms of methane production}

Methanogens are prokaryotic microorganisms belonging to the archaeal kingdom. Methanogenic archaea are obligate methane producers, which generate almost all biogenic methane as the end-product of anaerobic respiration to gain energy. All methanogens belong to the Euryarchaeota [62]. A genome-centric metagenomics has evidenced a methane metabolism in the archaeal phylum Bathyarchaeota [22], thus suggesting a wide phylogenetic and ecological diversity of microorganisms possessing methanogenic ability. The common habitats of methanogens include sediments, anaerobic soils, geothermal systems, landfill, livestock, termites, wastewater, sewage sludges and anaerobic digesters [5,22,35,119,125]. Accordingly, biomethane is both a renewable fuel source when produced in industrial plants, and a greenhouse gas contributing to global warming when methane is emitted into the atmosphere [4].

Methanogenic archaea actually includes 4 classes, 6 orders, 14 families, 29 genera and 155 species [34]. Known methanogenic pathways are few, they occur at the last steps of biomass decomposition. Substrates for methanogenesis are produced from macromolecules by

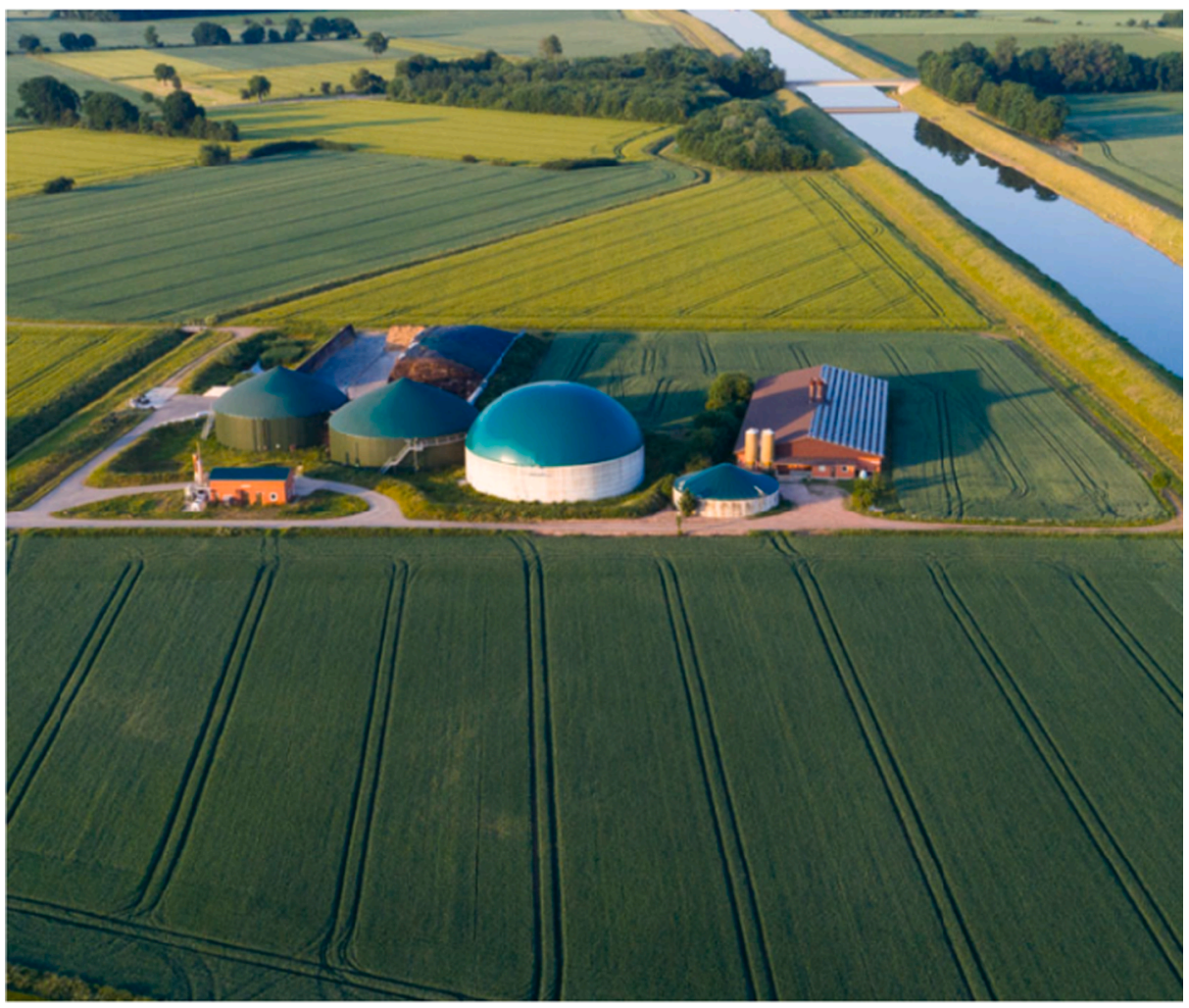

Fig.1. Biomethane production in an agricultural area in France. Copyright: Cedigaz 2020. 
Table 1

Studies of conductive materials on pure culture or co-culture of methanogens.

\begin{tabular}{|c|c|c|c|c|c|c|}
\hline $\begin{array}{l}\text { Anaerobic } \\
\text { system }\end{array}$ & substrate & $\begin{array}{l}\text { Conductive } \\
\text { material }\end{array}$ & $\begin{array}{c}\text { Applied } \\
\text { concentration(dose) }\end{array}$ & $\begin{array}{l}\text { Electron-donating } \\
\text { microorganisms }\end{array}$ & $\begin{array}{c}\text { Electron-accepting } \\
\text { microorganism }\end{array}$ & Reference \\
\hline Co-culture & Ethanol & Carbon cloth & $10,20 \mathrm{~g} / \mathrm{L}$ & Geobacter metallireducens & M. barkeri & [15] \\
\hline Co-culture & Ethanol & Ferrihydrite & $25 \mathrm{mM}$ & Geobacter & M. barkeri & [94] \\
\hline Co-culture & Ethanol & GAC & $25 \mathrm{~g} / \mathrm{L}$ & Geobacter metallireducens & M. barkeri & [58] \\
\hline Co-culture & Ethanol & Biochar & $26 \mathrm{~g} / \mathrm{L}$ & Geobacter metallireducens & M. barkeri & [16] \\
\hline Pure culture & Acetate & $\begin{array}{c}\text { Carbon } \\
\text { nanotubes } \\
\text { Carbon }\end{array}$ & $0.1,0.5,1,5 \mathrm{~g} / \mathrm{L}$ & NA & Methanosaeta concilii & [88] \\
\hline Pure culture & Acetate & nanotubes & $0.1,0.5,1,6 \mathrm{~g} / \mathrm{L}$ & NA & M. mazei & [88] \\
\hline Pure culture & Acetate & $\mathrm{NanoFe}_{3} \mathrm{O}_{4}$ & $4.64 \mathrm{mM}$ of $\mathrm{Fe}$ & NA & M. barkeri & [26] \\
\hline Pure culture & Acetate & $\begin{array}{c}\mathrm{NanoFe}_{3} \mathrm{O}_{4} \\
\text { Carbon }\end{array}$ & $4.65 \mathrm{mM}$ of $\mathrm{Fe}$ & NA & M. mazei & [110] \\
\hline Pure culture & Acetate & $\begin{array}{c}\text { nanotubes } \\
\text { Carbon }\end{array}$ & $0.2 \mathrm{~g} / \mathrm{L}$ & NA & M. barkeri & [128] \\
\hline Pure culture & Acetate & nanotubes & $0.2 \mathrm{~g} / \mathrm{L}$ & NA & M. mazei & [128] \\
\hline
\end{tabular}

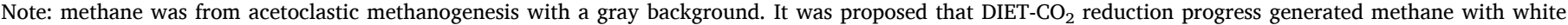
background. NA, not available. GAC: granular activated carbon.

hydrolysis, acidogenesis and acetogenesis in multi-community anaerobic environments (Fig. 2). Typically, complex organic matter is first cut into small particles by physicochemical and enzymatic processes. In particular, extracellular enzymes such as cellulases, hemicellulases, amylases, lipases and proteases are secreted by bacteria, e.g. Bacteroides and Streptococcus. Then, enzymes cut macromolecules into soluble substrates. During acidogenesis, soluble monosaccharides, amino acids and long-chain fatty acids are generated and further used by fermentative bacteria, involving both strict and facultative anaerobes. Then, during acetogenesis, metabolites such as butyrate and propionate are degraded into acetate. Overall, all these processes are controlling the efficiency of further methane generation.

During methanogenesis, methanogens gain energy by forming methane from 1-carbon and 2-carbon compounds, e.g. $\mathrm{CO}_{2}$ and acetate. For instance, hydrogenetrophic methanogens use $\mathrm{H}_{2}$ and $\mathrm{CO}_{2}$ as substrates to generate methane [18] (Eq. (1)):

$4 \mathrm{H}_{2}+\mathrm{CO}_{2} \rightarrow \mathrm{CH}_{4}+2 \mathrm{H}_{2} \mathrm{O}$ Hydrogenetrophic methanogenesis

Most cultivable methanogens are strict hydrogenotrophs, they use $\mathrm{H}$ electrons to reduce $\mathrm{CO}_{2}$ [34]. Some methanogenic archaea can also use electrons from other sources such as microbes and biocathodes as energy sources, a process named either direct electron transfer (DET), or direct interspecies electron transfer (DIET) when electrons are exchanged between two species [64]. For instance, DIET- $\mathrm{CO}_{2}$ reduction is operated by electroactive bacteria coupled to methanogenic archaea [86] (Eq. (2)):

$8 \mathrm{H}^{+}+8 \mathrm{e}^{-}+\mathrm{CO}_{2} \rightarrow \mathrm{CH}_{4}+2 \mathrm{H}_{2} \mathrm{O}$ DIET- $\mathrm{CO}_{2}$ reduction

Acetotrophic methanogens directly break acetate to generate methane [114] (Eq. (3)):

$\mathrm{CH}_{3} \mathrm{COO}^{-}+\mathrm{H}_{2} \mathrm{O} \rightarrow \mathrm{CH}_{4}+\mathrm{HCO}_{3}{ }^{-}$Acetoclastic methanogenesis

Here, the carboxyl group of acetate is first oxidized into $\mathrm{CO}_{2}$ and electrons. Electrons are then transferred to CoM-S-S-CoB that transforms the acetate methyl into methane [114]. This metabolism is responsible for $70-90 \%$ of the total methane produced during the anaerobic digestion of organic waste and in terrestrial environments [5,18]. Some methanogens use other methyl compounds such as methanol and methylamine as substrates to produce methane, which constitutes the third methanogenic pathway and contributes little to methane accumulation. Overall, three pathways are actually known to produce methane: hydrogenetrophic methanogenesis (MIET- $\mathrm{CO}_{2}$ and DIET- $\left.\mathrm{CO}_{2}\right)$, acetoclastic methanogenesis and methyltrophic methanogenesis.

Despite its major contribution to biomethane production, acetoclastic methanogenesis is performed to only two genera, Methanosarcina and Methanosaeta. Methanosarcina is a versatile methanogen able to use the three metabolic pathways, whereas Methanosaeta feeds only on acetate. In 2014, it was observed that Methanosaeta can accept electrons provided by Geobacter to reduce $\mathrm{CO}_{2}$ to generate methane [86]. Methanosaeta is able to process acetate very efficiently, even at acetate levels as low as $5 \mu \mathrm{M}$ [114]. By contrast, Methanosarcina requires a minimum concentration of about $1 \mathrm{mM}$. The distinct acetate affinity may explain the differences in the first step of the acetate metabolism. The lowaffinity acetate kinase-phosphotransacetylase system is used to activate acetate to generate acetyl-CoA in Methanosarcina, while Methanosaeta employs the high-affinity adenosine monophosphate forming acetyl-CoA [114]. In addition, genome sequence analysis suggests that Methanosarcina and Methanosaeta probably use different modes of electron transfer and energy conservation. Recent advances in acetoclastic methanogenesis have been recently summarized by Evans et al. [21] and Welte and Deppenmeier [114].

\section{3. $\mathrm{CO}_{2}$ reduction to methane}

Two mechanisms explain reduction of $\mathrm{CO}_{2}$ into methane, mediated interspecies electron transfer (MIET) and direct interspecies electron transfer (DIET).

\subsection{Mediated interspecies electron transfer}

Efficient methanogenesis is observed when there is a syntrophy between fermentative bacteria and methanogenic archaea. The syntrophic species take advantage of the metabolism of the partner species to overcome thermodynamic barriers, thus enabling to break intermediates that are otherwise difficult to break [92]. The two core processes, organic degradation and methane production, highly depend on the efficiency of interspecies electron transfer [92]. Historically, interspecies electron transfer has referred to mediated interspecies electron transfer with $\mathrm{H}_{2}$ or formate as electron carriers, named respectively interspecies hydrogen transfer (IHT) and interspecies formate transfer (IFT). During anaerobic digestion, digestion and methanogenesis activities reach a balance where $\mathrm{H}_{2}$ produced by the syntrophic bacteria is 
Table 2

Studies of conductive materials on microbial consortium. (See below-mentioned references for further information.)

\begin{tabular}{|c|c|c|c|c|c|c|}
\hline Research subject & $\begin{array}{c}\text { Inoculum/Substra } \\
\text { tes }\end{array}$ & Conductive materials & Dose & $\begin{array}{l}\text { Predominant } \\
\text { bacteria }\end{array}$ & $\begin{array}{l}\text { Predominant } \\
\text { methanogens }\end{array}$ & Reference \\
\hline Synthetic brewery wastewater & $\begin{array}{c}\text { Seed } \\
\text { sludge/glucose }\end{array}$ & GAC & $5 \mathrm{~g} / \mathrm{L}$ & Proteiniphilum & Methanosarcina & [130] \\
\hline Food waste & $\begin{array}{l}\text { Anaerobic } \\
\text { digester sludge }\end{array}$ & GAC & $25 \mathrm{~g} / \mathrm{L}$ & Firmicutes & Methanosarcina & [87] \\
\hline Feeding medium & $\begin{array}{c}\text { Seed } \\
\text { sludge/glucose }\end{array}$ & GAC & $10 \mathrm{~g} / \mathrm{L}$ & Actinobacteria & Methanosaeta & [132] \\
\hline Anaerobic soil & Glucose & GAC & $1 \mathrm{~g} / \mathrm{L}$ & NA & Methanosaeta & [120] \\
\hline Waste activated sludge & Seed sludge & GAC & $27 \mathrm{~g} / \mathrm{L}$ & anaerolineaceae & Methanosaeta & [77] \\
\hline Organic wastewater & $\begin{array}{c}\text { Anaerobic } \\
\text { sludge/acetate } \\
\text { Sludge/fructose }\end{array}$ & GAC & $10 \mathrm{~g} / \mathrm{L}$ & gracilibacter & Methanosaeta & [99] \\
\hline Packing media & $\begin{array}{l}\text { and polyethylene } \\
\text { glycol }\end{array}$ & GAC & NA & Geobacter & Methanosaeta & [73] \\
\hline Anaerobic sludge & Propionate & GAC & NA & Syntrophobacte & Methanosaeta & [135] \\
\hline Anaerobic sludge & Acetate & GAC & NA & Syntrophobacte & Methanosaeta & [135] \\
\hline Synthetic wastewater & $\begin{array}{c}\text { Anaerobic } \\
\text { sludge/glucose }\end{array}$ & GAC & $10 \mathrm{~g} / \mathrm{L}$ & NA & Methanosaetaceae & [124] \\
\hline Food waste & Seed sludge & Activated carbon & $5,15,25,35 \mathrm{~g} / \mathrm{L}$ & Smithella & Methanosaeta & [142] \\
\hline Synthetic wastewater & $\begin{array}{c}\text { Seed } \\
\text { sludge/VFAs }\end{array}$ & Activated carbon & $5 \mathrm{~g} / \mathrm{L}$ & Syntrophomonas & Methanosaeta & \\
\hline $\begin{array}{l}\text { Flammulina velutipes } \\
\text { residues }\end{array}$ & $\begin{array}{c}\text { seed } \\
\text { sludge/NFAs }\end{array}$ & Particle activated carbon & $14.3 \mathrm{~g} / \mathrm{L}$ & VadinBC27 & Methanosarcina & [54] \\
\hline Synthetic wastewater & $\begin{array}{c}\text { Seed } \\
\text { sludge/VFAs }\end{array}$ & $\begin{array}{l}\text { Iron modified activated } \\
\text { carbon }\end{array}$ & $5 \mathrm{~g} / \mathrm{L}$ & Syntrophomonas & Methanosaeta & \\
\hline Basic nutrient solution & $\begin{array}{c}\text { Granular } \\
\text { sludge/glucose }\end{array}$ & Biochar & $10 \mathrm{~g} / \mathrm{L}$ & Enterobacteriaceae & Methanosaeta & [66] \\
\hline Synthetic wastewater & $\begin{array}{c}\text { Seed } \\
\text { sludge/sucrose }\end{array}$ & Biochar & $4 \mathrm{~g} / \mathrm{L}$ & Bacteroidetes & Methanosaetaceae & [52] \\
\hline Food waste & Seed sludge & Biochar & $10 \mathrm{~g} / \mathrm{L}$ & Fenvidobacterium & Methanosaeta & [53] \\
\hline Food waste & Activated sludge & Biochar & $2,6,10$ and $15 \mathrm{~g} / \mathrm{L}$ & Anaerolineaceae & Methanosaeta & [108] \\
\hline Chicken manure feed & Seed sludge & Biochar & NA & Bacteroidia & Methanosarcina & [74] \\
\hline Anaerobic soil & Acetate & Biochar & $1 \mathrm{~g} / \mathrm{L}$ & Lentimicrobiaceae & Methanosarcina & \\
\hline Synthetic wastewater & $\begin{array}{c}\text { Anaerobic } \\
\text { sludge/glucose }\end{array}$ & Biochar & $1 \mathrm{~g} / \mathrm{L}$ & NA & Methanosaetaceae & [124] \\
\hline Dog food & Seed sludge & Carbon cloth & 3 pieces $/ L$ & Sporanaerobacter & Methanosarcina & [19] \\
\hline Anaerobic soil & Straw & Carbon cloth & 3 pieces/Vial & Mobilitalea & Methanosarcina & [52] \\
\hline Artificial wastewater & $\begin{array}{c}\text { Seed } \\
\text { sludge/propionate }\end{array}$ & Graphite felt & NA & Smithella & Methanosaeta & [143] \\
\hline Artificial wastewater & $\begin{array}{c}\text { Seed } \\
\text { sludge/butyrate } \\
\text { Anaerobic }\end{array}$ & Graphite felt & NA & Syntrophomonas & Methanosaeta & [143] \\
\hline Propionate-butyrate medium & $\begin{array}{l}\text { sludge/propionat } \\
\text { e and butyrate }\end{array}$ & Carbon felt particles & $1583 \mathrm{~m}^{2} / \mathrm{m}^{3}$ & Desulfuromonas & Methanosaeta & [9] \\
\hline Wastewater & Seed sludge & $\begin{array}{l}\text { Nitrogen doped sewage } \\
\text { sludge carbon }\end{array}$ & $5 \mathrm{~g} / \mathrm{L}$ & $\begin{array}{c}\text { Saccharofermentant } \\
s\end{array}$ & Methanosaeta & [52] \\
\hline Synthetic wastewater & $\begin{array}{l}\text { Anaerobic } \\
\text { sludge/glucose }\end{array}$ & Graphene & $0.1 \mathrm{~g} / \mathrm{L}$ & NA & Methanosaetaceae & [124] \\
\hline Coal gasification wastewater & $\begin{array}{l}\text { Seed sludge } \\
\text { Anaerobic }\end{array}$ & Graphene & $0.2,0.5$ and $1.0 \mathrm{~g} / \mathrm{L}$ & $\begin{array}{l}\text { Saccharofermentant } \\
\quad s \text { and afipia }\end{array}$ & Methanosaeta & [149] \\
\hline Basal medium & $\begin{array}{c}\text { granular } \\
\text { sludge/Sucrose }\end{array}$ & Carbon nanotubes & $1 \mathrm{~g} / \mathrm{L}$ & Clostridiales & Methanosaeta & [53] \\
\hline Anaerobic soil & Glucose & Carbon nanotubes & $0.2 \mathrm{~g} / \mathrm{L}$ & NA & Methanosarcina & [120] \\
\hline waste activated sludge & Seed sludge & GAC@Magnetite & $27 \mathrm{~g} / \mathrm{L}$ & prolixibacteraceae & Methanosaeta & [77] \\
\hline Anaerobic paddy soil & Sodium acetate & Magnetite & $20 \mathrm{mM}$ & $\begin{array}{l}\text { Clostridium and } \\
\text { Geobacter }\end{array}$ & Methanosarcina & [41] \\
\hline waste activated sludge & Seed sludge & Magnetite & $27 \mathrm{~g} / \mathrm{L}$ & anaerolineaceae & Methanosaeta & [77] \\
\hline Synthetic wastewater & $\begin{array}{c}\text { Anaerobic } \\
\text { sludge/glucose }\end{array}$ & Magnetite & $4.62 \mathrm{~g} / \mathrm{L}$ & NA & Methanosaetaceae & [124] \\
\hline Fresh leachate & Sludge & Magnetite & $10 \mathrm{~g} / \mathrm{L}$ & Eubacteriaceae & Methanosaeta & [49] \\
\hline Fischer-Tropsch wastewater & NA & Magnetite & $0.1,0.2$ and $0.3 \mathrm{~g} / \mathrm{L}$ & Geobacter & Methanosaeta & [108] \\
\hline Synthetic wastewater & $\begin{array}{l}\text { Ethanol, acetate } \\
\text { and propionate }\end{array}$ & $\mathrm{Fe}_{3} \mathrm{O}_{4}$ & $10 \mathrm{~g} / \mathrm{L}$ & Mesotoga & Methanosaeta & [61] \\
\hline Whey & $\begin{array}{l}\text { Anaerobic seed } \\
\text { sludge }\end{array}$ & Magnetite & $20 \mathrm{mM}$ & Clostridium & Methanosaeta & [7] \\
\hline Basal medium & $\begin{array}{c}\text { Anaerobic } \\
\text { sludge/acetate }\end{array}$ & Magnetite & $25 \mathrm{mM}$ & Geobacteraceae & Methanosarcina & [151] \\
\hline Synthetic wastewater & $\begin{array}{c}\text { Anaerobic } \\
\text { sludge/tryptone }\end{array}$ & $\mathrm{Fe}_{3} \mathrm{O}_{4}$ & $10 \mathrm{~g} / \mathrm{L}$ & Proteiniclasticum & Methanosarcina & [138] \\
\hline Inorganic medium & $\begin{array}{c}\text { Seed } \\
\text { sludge/acetate } \\
\text { and propionate }\end{array}$ & Magnetite & 5 and $10 \mathrm{mM}$ & $\begin{array}{l}\text { Tepidanaerobacter } \\
\text { syntrophicus }\end{array}$ & Methanosarcina & [131] \\
\hline Synthetic wastewater & $\begin{array}{l}\text { Inoculated } \\
\text { sludge/sucrose }\end{array}$ & Magnetite & $10 \mathrm{~g} \mathrm{Fe} / \mathrm{L}$ & Chloroflexi & Methanosarcina & [106] \\
\hline Anaerobic soil & Straw & Nano-magnetite & $20 \mathrm{mM}$ & Bacillus & Methanosarcina & [121] \\
\hline Anaerobic soil & Acetate & Magnetite & $25 \mathrm{mM}$ & Proteobacteria & Methanosarcina & [148] \\
\hline Basal medium & $\begin{array}{l}\text { Anaerobic } \\
\text { soil/straw }\end{array}$ & $\mathrm{NanOFe}_{3} \mathrm{O}_{4}$ & $2.1 \mathrm{mM}$ & NA & Methanosarcina & [83] \\
\hline Dairy farm wastewater & Inoculated sludge & Magnetite & $2.5 \mathrm{~g} / \mathrm{L}$ & Clostridium & Methanosarcina & [85] \\
\hline $\begin{array}{l}\text { Fresh water enrichment } \\
\text { medium }\end{array}$ & $\begin{array}{l}\text { Anaerobic } \\
\text { soil/acetate }\end{array}$ & Amorphous iron & $100 \mathrm{mM}$ & serratia & Methanosarcina & [126] \\
\hline Inorganic medium & $\begin{array}{l}\text { Anaerobic } \\
\text { soil/acetate }\end{array}$ & Ferrihydrite & $20 \mathrm{mM}$ & Geobacter & Methanosarcina & [42] \\
\hline Synthetic wastewater & $\begin{array}{c}\text { Seed } \\
\text { sludge/VFAs }\end{array}$ & Goethite & $5 \mathrm{~g} / \mathrm{L}$ & Syntrophomonas & Methanosaeta & \\
\hline Basal medium & $\begin{array}{l}\text { Mixture of oil and } \\
\text { water }\end{array}$ & Akaganéite & $25 \mathrm{mM}$ & Halomonas & Methanosaeta & [75] \\
\hline
\end{tabular}

Note: Methane production was mainly from acetoclastic methanogenesis with a gray background. On the contrary, DIET-CO ${ }_{2}$ reduction predominantly contributed to methane accumulation. GAC: granular activated carbon. VFAs: VFAs. NA, not available. 
used timely by methanogens [141]. Nevertheless, electron diffusion is limited by electron carriers and, in turn, MIET efficiency is relatively low $[63,64]$. At high hydrogen pressure, above $10 \mathrm{~Pa}$, fermentative bacteria is inhibited due to a thermodynamically unfavorable reaction, with $\Delta \mathrm{G}$ above 0 . As a consequence, hydrogenase activity and metabolism of syntrophic bacteria are low.

In the $2000 \mathrm{~s}$, interspecies electron transfer was known to be mediated only by compounds, e.g. formate and bihydrogen. Later, in the past decade, DIET has been proposed as a more efficient and energy-saving mechanism, compared to MIET [64]. DIET involves electrically conductive pili as conduit to transfer electrons from one species to the other. DIET thus avoids energy consumption for the production and consumption of the MIET intermediates $[63,64]$. The stability of DIET is optimal in methanogenic biofilm aggregates $[50,63]$. DIET improves the competitiveness for electroactive microorganisms. For instance, volatile fatty acids (VFAs) are used by some anaerobic bacteria except for electroactive microorganisms. Here DIET provides a selective advantage for electron-donating bacteria over other anaerobic bacteria.

\subsection{Direct interspecies electron transfer}

DIET proceeds either biologically or by conductive materials. Biological DIET involves conductive pili (e-pili) and c-type cytochrome. A pilus is a hair-like appendage on the surface of many bacteria and archaea. Two mechanisms have been proposed to explain e-pili conduction: metal-driven conduction where charges spread across the entire filament by pi-pi orbital overlaps and charge delocalization $[100,103]$. For pi-pi orbital overlaps, electron density can be transferred form filled ligand orbital to the empty d-orbital of the metal center, or from the filled d-orbital of the metal to the empty orbital of the ligand. Charge delocalization is a stabilizing force because it spreads energy over a larger area rather than keeping it confined to a small area. Since electrons are charges, the presence of delocalized electrons brings extra stability to a system compared to a similar system where electrons are localized [100]. Electron tunneling in the pili-embedded cytochrome can be completed [64]. Co-cultures and anaerobic digestion thus benefit from e-pili-mediated DIET.

Alternatively, electroactive microorganisms that lack e-pili and other electron-bridging organs can still perform DIET artificially by addition of conductive materials such as carbon-based conductors or metals to the medium $[16,59]$. Here electrons are transferred at the material surface, which is supported by Shrestha et al. [91] who found a correlation of $\mathrm{r}$ of 0.67 between abundance of Geobacter spp., where Geobacter can also accept electrons from abiotic resource [116], and granule conductivity. Other studies also showed that enhanced methane production by conductive materials is correlated with electron redox transfer [139]. As a consequence, direct electron transfer properties of conductive materials may contribute little for electromethanogenesis [102].

Magnetite is highly conductive, and is thus a common iron-bearing mineral used in DIET to enhance methane production. Guskos et al. [29] showed that magnetite electrical conductivity reaches $2.5 \times 10^{2}$ $\Omega \cdot \mathrm{cm}^{-2}$, versus $2 \mathrm{M} \Omega \cdot \mathrm{cm}$ for hematite and $16 \mathrm{M} \Omega \cdot \mathrm{cm}$ for goethite. In systems involving propionate as substrate, propionate is oxidized to acetate via two possible reactions [13] (Eqs. (4) and (5)):

$\mathrm{CH}_{3} \mathrm{CH}_{2} \mathrm{COO}^{-}+3 \mathrm{H}_{2} \mathrm{O} \rightarrow \mathrm{CH}_{3} \mathrm{COO}^{-}+\mathrm{H}^{+}+3 \mathrm{H}_{2}$ Interspecies hydrogen transfer (IHT)

$\mathrm{CH}_{3} \mathrm{CH}_{2} \mathrm{COO}^{-}+0.75 \mathrm{H}_{2} \mathrm{O} \rightarrow \mathrm{CH}_{3} \mathrm{COO}^{-}+0.25 \mathrm{HCO}_{3}^{-}+0.25 \mathrm{H}^{+}+$ $0.75 \mathrm{CH}_{4}$ DIET

DIET is favored because the Gibbs free energy induced by magnetite in DIET, $\Delta \mathrm{G}^{0}$ of $-26.4 \mathrm{~kJ} / \mathrm{mol}$, is much more negative than that in IHT, of $+72.7 \mathrm{~kJ} / \mathrm{mol}$ [38]. It suggests the obvious preference of DIET rather than IHT during anaerobic digestion in the presence conductive Febearing mineral, which benefits methane production. Similarly, magnetite induced a 3-fold increase of methane production with butyrate as substrate [51]. It was speculated that DIET-promoting effect of magnetite is due to magnetite conductivity. Wang et al. [104,110] proposed that magnetite had different promoting effects on methanogenic degradation of different substrates, and magnetite facilitated different syntrophic partners in different stages. Another mechanism involving $\mathrm{Fe}(\mathrm{II}) / \mathrm{Fe}$ (III) redox cycling may also accelerate the transfer of electrons. This was recently confirmed during acetoclastic methanogenesis, which was accelerated and correlated with redox cycling of magnetite $\mathrm{Fe}(\mathrm{II}) / \mathrm{Fe}(\mathrm{III})$ in pure cultures of Methanosarcina [26,110].

In the same vein, it is widely accepted that the high conductivity of conductive materials strengthens DIET. For example, the conductivity of biochar and granular activated carbon, of $2-5$ and $3000 \mu \mathrm{S} / \mathrm{cm}$, suggests their potential to perform DIET $[16,58]$. Yet the stimulation efficiencies of DIET by biochar and granular activated carbon for methane production are similar despite their different conductivities. Therefore, electrical conductivity is not the sole factor controlling improved methane production. Other possible factors include the redox potential, the specific surface area and the roughness of conductive materials.

\section{Acetoclastic methanogenesis versus DIET- $\mathrm{CO}_{2}$ reduction}

DIET- $\mathrm{CO}_{2}$ reduction has been proposed to explain enhanced methane production when conductive materials are added, as a result of high conductivity [129]. However, microbial diversity analysis in most studies reveal that Geobacter pp. were minor in abundance or even absent $[71,128]$. Table 2 confirms that the predominant bacteria in anaerobic fermentation are not electricity-producing microorganisms (electricigens) but the fermentative microorganisms. When electricigens are undetectable, other bacteria have been suggested to be involved in DIET: for example, Lei et al. [48] showed that Syntrophomonas sp. exchange electrons directly with Methanospirillum hungatei via a carbon cloth. Yet, a co-culture study showed that $M$. hungatei is unable to accept electrons directly from electricigen to reduce $\mathrm{CO}_{2}$ [86] .

DIET is still proposed as the main mechanism to interpret unexpected results of anaerobic digestion. Indeed, other possible mechanisms are overlooked by the actual research focus on Geobacter species and other electroactive bacteria. Several insights suggest the occurrence of another mechanism. For example, to study the contribution of electrodes and electric current to process stability and methane production during the electro-fermentation of food waste, the authors demonstrated that Geobacter occurred at the cathode with a low abundance [61]. Electric current stimulated the growth of hydrogenotrophic methanogens, but acetotrophic Methanosaeta still made up 27.6-61.9\% of archaeal community. For the function of conductive materials, magnetite accelerates the oxidation of propionate by acting as an electron acceptor, rather than promoting DIET [136]. Moreover, carbon nanotubes promoted methanogenic activities of four different species of methanogenic archaea growing in pure cultures [88], thus proving that the effect of conductive materials are not solely due to interactions between different species. Recently, Lu et al. [65] proposed that redox-active biochar and conductive graphite stimulated methanogenic metabolism in anaerobic digestion of waste-activated sludge: beyond direct interspecies electron transfer. Both graphite and biochar increased methane production primarily by enhancing the acetoclastic pathway, while syntrophic acetate oxidation via DIET was not thermodynamically favorable. Therefore the mechanism by which conductive materials enhance methane generation is open to debate.

Findings in the last several years show that conductive materials can promote methane production by direct acetate dismutation (acetoclastic methanogenesis), alternatively to DIET- $\mathrm{CO}_{2}[26,65,128]$. Indeed, under the stressful conditions, which is often encountered during anaerobic fermentation, the rate limiting step is usually acetoclastic methanogenesis [5]. This is supported by experimental and modelled data of growth of acetoclastic methanogens, thus lowering the contribution of $\mathrm{CO}_{2}$ reduction [76]. We provided unambiguous evidence for promotion 


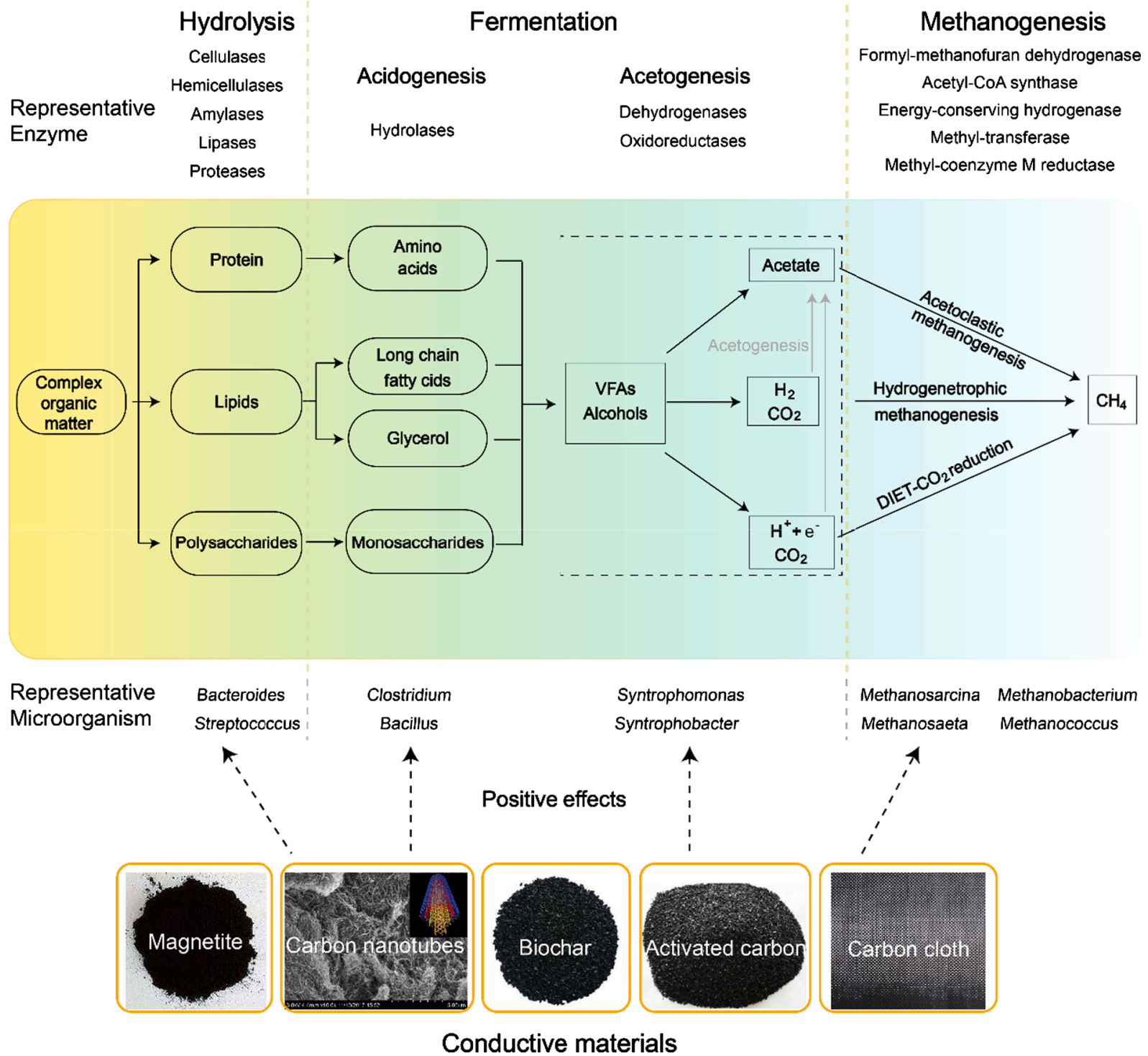

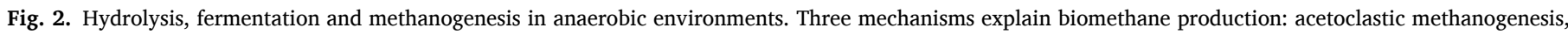

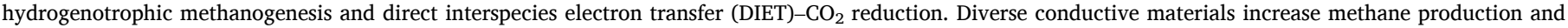
mineralization.

of acetoclastic methanogenesis rather than $\mathrm{CO}_{2}$ reduction, in a Methanosarcina spp. culture with carbon nanotubes, using isotope tracing and $\mathrm{CH}_{3} \mathrm{~F}$ inhibition [128]. Here, the metabolism involved in the electron donating half-reaction - the carboxyl oxidation - is up-regulated (Fig. 3a). Furthermore, nanotubes were stuck tightly to the cell surfaces, suggesting that electron transfer mediated by nanotubes may accelerate the entire chain of electron transfer (Fig. 3a).

Moreover, magnetite can act as an electron shuttle to accelerate intracellular electron transfer, thus improving direct acetate dismutation of $M$. barkeri [26] (Fig. 3b). Here, nanoFe ${ }_{3} \mathrm{O}_{4}$ passes through the cell membrane of $M$. barkeri, and transfers electron in a similar manner as membrane-bound methanophenazine. Another investigation also showed that magnetite accelerated the production of methane by acetoclastic methanogenesis, which was interpreted by magnetite redox ability [104,110] (Fig. 3c). Interestingly, the authors showed that $\mathrm{NanoFe}_{3} \mathrm{O}_{4}$ did not enter into cells, contrary to Fu et al. [26]. Wang et al. $[104,110]$ thus proposed that an outer-surface multiheme cytochrome and surface proteins accepted electrons from $\mathrm{NanoFe}_{3} \mathrm{O}_{4}$, thus promoting membrane electron transfer and acetoclastic methanogenesis. The redox cycling of nanoFe ${ }_{3} \mathrm{O}_{4}$ delivered a positive effect via the multiheme c-type cytochrome to the membrane electron transfer and hence promoted acetoclastic methanogenesis. It was also recently verified by our group via proteome analysis [60]. Therefore the mechanisms by which conductive materials promote the acetoclastic methanogenesis are probably not only the three mechanisms presented in Fig. 3.

In complex microbial communities we found that conductive materials promote both DIET- $\mathrm{CO}_{2}$ reduction and acetoclastic methanogenesis [124]. Acetoclastic methanogenesis was also evidenced by addition of magnetite in wastewater [85]. Here, improved methane production was attributed to the formation of dense planktonic cell co-aggregates glued by magnetite, which facilitated interspecies electron exchange. Metatranscriptomic data further showed that genes involved in acetoclastic methanogenesis were highly expressed after addition of granular activated carbon, indicating that Methanosaeta was metabolically active and contributed to methane accumulation via acetoclastic methanogenesis [135]. About 4/5 of the methane rise was explained by acetoclastic methanogenesis. Evidence for the predominance of acetoclastic methanogenesis rather than DIET- $\mathrm{CO}_{2}$ was definitively provided in the study of anaerobic soils by ${ }^{13} \mathrm{C}$ tracing, $\mathrm{CH}_{3} \mathrm{~F}$ methanogenic inhibition, proteome analysis, thermodynamic analysis, electrochemical analysis, 
modelling and microscopy [128]. Indeed, isotope tracing gives solid proof that methane originates from acetoclastic methanogenesis in the presence of conductive materials [26,120,124,128].

\section{Acetotrophic methanogens and conductive materials}

The major methanogenic archaea capable of using acetate and $\mathrm{CO}_{2}$ are the acetotrophic methanogens Methanosarcina and Methanosaeta [34]. Recent advances on the use of conductive materials with Methanosarcina and Methanosaeta are summarized in Table 2.

\subsection{Methanosarcina}

Enhanced anaerobic digestion and methane production has been explained by the fact that Methanosarcina is enriched by the presence of conductive materials. For instance, addition of granular activated carbon increased the efficiency of dry anaerobic digestion of swine manure and methane generation [87]. Similarly, biochar strengthened the synergy between electricigens and Methanosarcina [74,57]. Here, Viggi et al. [102] demonstrated that biochar favored the growth of Methanosarcina over Methanosaeta during anaerobic digestion and methane production. Carbon cloth is also improving co-cultures and anaerobic digestion. For instance, Sporanaerobacter and Methanosarcina were enriched at the surface of carbon cloth surface during digestion of organic wastes [19]. Findings from our group also confirmed the acceleration of carbon cloth on methane generation [52]. Here, isotope tracing showed that higher methane production was mainly due to acetoclastic methanogenesis by Methanosarcina. We further showed that carbon nanotubes and graphene of high electrical conductivity stimulated methane generation by both $\mathrm{CO}_{2}$ reduction and direct acetate dismutation, with a predominant contribution of Methanosarcina [124].

Metal-based materials also stimulate methane generation by Methanosarcina. Conductive iron oxides facilitated methane generation from propionate and acetate, and enhanced hydrolysis and acidification [131]. Magnetite induced the enrichment of electricigens and Methanosarcina efficiently in anaerobic sludges and soils [106]. Stimulation of methanogenesis by syntrophy between electroactive microorganisms and Methanosarcina with magnetite was revealed in anaerobic soils. For instance, nanoFe $\mathrm{O}_{4} \mathrm{O}_{4}$ stimulated the degradation of methanogenic straw in paddy soils, with a concomitant rise of Methanosarcina abundance [83]. The conductivity of Fe(III) oxides was proposed as a major factor explaining methanogenesis [148]. In wetland soils, nano- $\mathrm{Fe}_{3} \mathrm{O}_{4}$ particles accelerated electromethanogenesis rapidly by Methanosarcina, within several hours [121].

In situ biogenic magnetite located in a red clay horizon was also proposed to promote DIET for generating methane by Methanosarcina [126]. Similarly, the co-occurence of sulfate and iron oxide promoted methane production by biogenic, semiconductive iron sulfides, which in turn induced faster methane production via electric syntrophy [42]. Moreover, biogenic magnetite was identified as the main contributor to promote DIET between Geobacter and Methanosarcina in a manner similar to that of c-type cytochrome [94]. Overall, most investigations attribute rising methane production to DIET- $\mathrm{CO}_{2}$ reduction, yet only by indirect evidence. Moreover, metatranscriptomic studies disclosed that genes coding for acetoclastic methanogenesis, not genes for $\mathrm{CO}_{2}$ reduction, were abundantly expressed in Methanosarcina with nanomagnetite [35]. Overall the respective contributions of DIET- $\mathrm{CO}_{2}$ reduction and direct acetate dismutation requires further investigations.

\subsection{Methanosaeta}

Methanosaeta has a much higher affinity for acetate than Methanosarcina [36], making Methanosaeta more competitive in anaerobic environments where acetate levels are low $[14,25]$. Studies on DIET showed a substantial enrichment of 16S rRNA gene sequences closely related to Geobacter and Methanosaeta species on biochar surface [105].
Syntrophy of Anaerolineaceae and Methanosaeta on biochar was proposed to explain higher methane production during anaerobic digestion of organic wastes [108]. Moreover, conductive carbon felt favored the formation of biofilms on anaerobic granules, the formation of Methanosaeta-containing microbiome, to reduce propionate accumulation, and enhance methanogenic co-degradation of propionate and butyrate [9].

Granular activated carbon was also used to enrich Methanosaeta species and to improve anaerobic sludge digestion by converting acetate to methane [77]. Molecular and microbial evidence showed that granular activated carbon enriched simultaneously Methanosaeta and fermentative bacteria, Syntrophorhabdus and Synergistes, during the degradation of organic compounds, which in turn facilitated methane production [99]. Granular activated carbon addition also favored syntrophy between recently-identified Geobacter species and Methanosaeta, thus enhancing methane generation [73]. This synthrophy was confirmed by bioinformatic analysis, which showd that activated carbon should induce the formation of a dense syntrophic microbial network [142]. Furthermore, graphene addition induced the enrichment of Geobacter and Methanosaeta during anaerobic degradation of coal gasification wastewater, and improved both methane production and the removal of the chemical oxygen demand [149].

Magnetite was found particularly effective in promoting degradation of butyrate, propionate and acetate; it was suggested here that magnetite bridged exoelectrogens and Methanosaeta species [108]. Magnetite also probably triggered DIET between Syntrophomonas, or Trichococcus, and Methanosaeta when dairy wastewater was digested anaerobically with activated sludges [7]. Addition of akaganéite, an iron oxyde/hydroxide mineral of $\left(\mathrm{Fe}^{3+}, \mathrm{Ni}^{2+}\right)_{8}(\mathrm{OH}, \mathrm{O})_{16} \mathrm{Cl}_{1.25} \mathrm{nH}_{2} \mathrm{O}$ formula, into a hightemperature petroleum reservoir, promoted methane production by shifting the methanogenic pathway from hydrogenotrophic methanogenesis fueled by syntrophic acetate oxidizers to acetoclastic methanogenic [75].

Some studies also reported that both Methanosaeta and Methanosarcina promoted anaerobic digestion and methane production. Here, conductive materials facilitated electron exchange via DIET in the syntrophic oxidation of VFAs, resulting in efficient methane production using biochar, graphite felt and goethite [53,132,143]. Noteworthy, biochar was used to alleviate the stress of ammonium and acids by firstly enriching Methanosaeta, then Methanosarcina [66]. Methanosarcina, Methanosaeta and magnetite further enhanced the anaerobic treatment of solid and liquid wastes [46,49]. Moreover, conductivity and levels of extracellular polymeric substances of anaerobic sludges were remarkably increased by adding $\mathrm{N}$-doped sewage sludge $\mathrm{C}$, suggesting that DIET was involved with Methanosaeta and Methanosarcina as terminal contributors [150].

\section{Benefits of conductive materials}

It has been widely observed that conductive materials improve methane production by facilitating DIET, yet precise DIET mechanisms are still obscure [152]. Addition of conductive materials immobilize microorganisms, thus promoting biofilm growth, regulating $\mathrm{pH}$ and oxidation-reduction potential, which favors acetotrophic methanogens and potential acetoclastic methanogenesis [72,84,152] (Fig. 4). Several mechanisms seem to be better than electron transfer: the activation on iron-containing enzymes involved in methanogenesis and acidogenesis, selective enrichment on functional microorganism, and high electron donating capacities. Some limitations of these materials, however, was proposed as well, such as sterilization properties of carbon nanotubes, high cost of graphene, and not reusable for almost conductive materials. Here we present the positive effects of adding conductive materials.

\subsection{Microbial immobilization}

The binding and colonization of microbes on solids is known to 


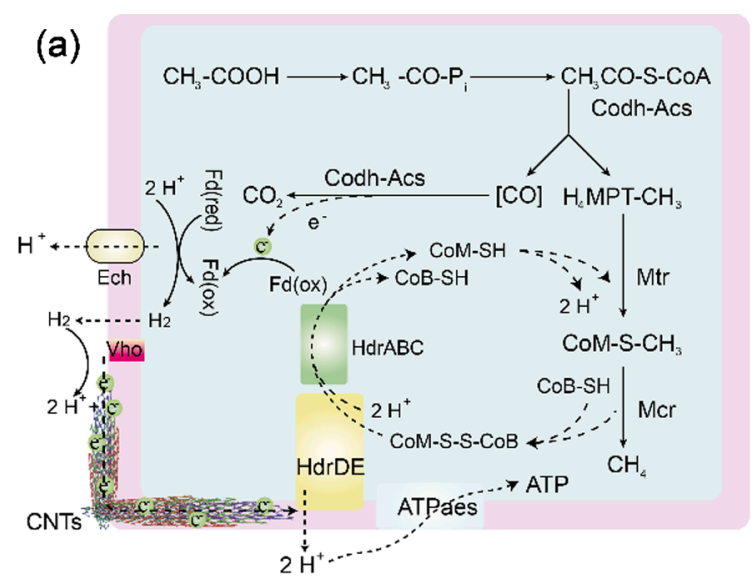

(b)

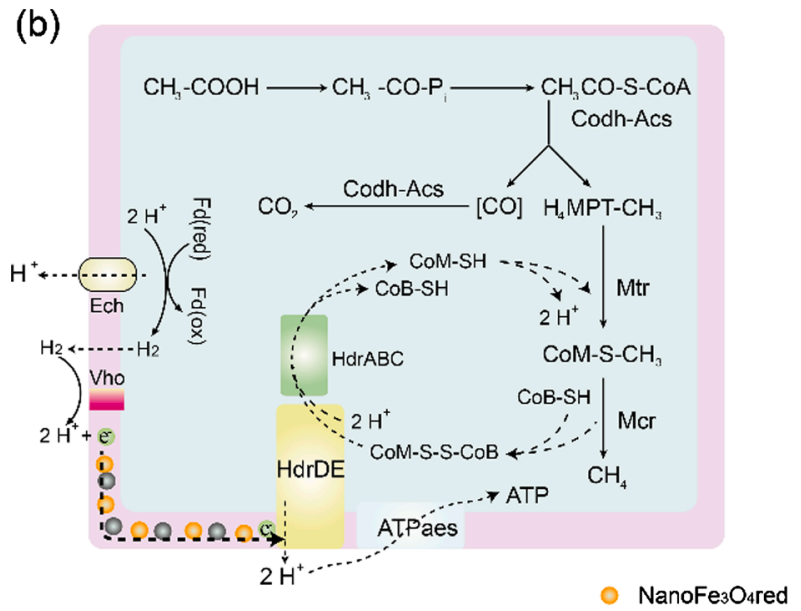

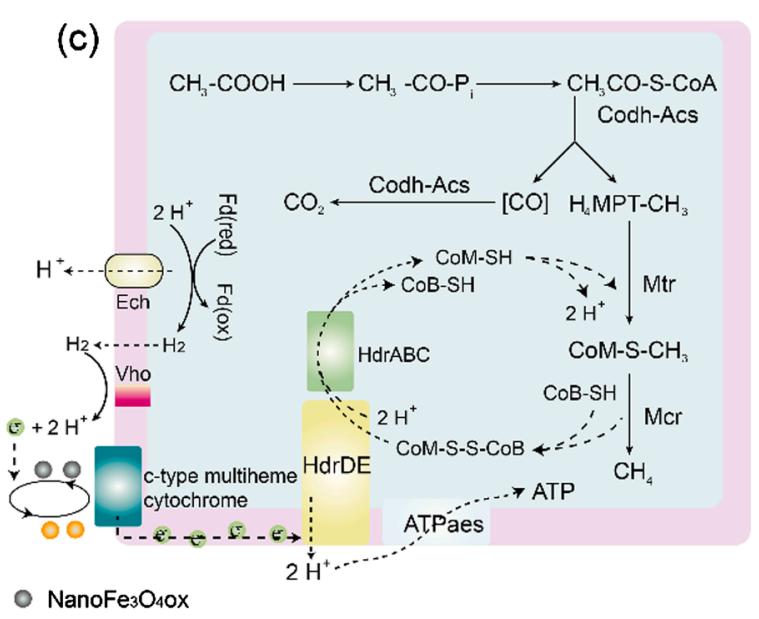

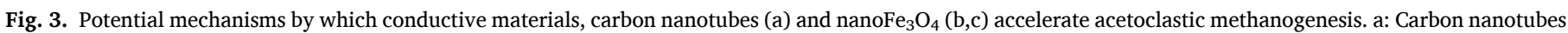

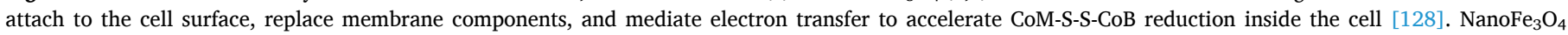
particles act as solid electron shuttles to mediate electron transfer inside the cell (b, [26] and outside the cell (c, [110].

increase activity and syntrophy $[15,58,67]$. Microbial adherence is controlled by the adsorption capacity of materials, which in turn depends on surface morphology, pore volume and size, hydrophobicity and ion-exchange capacity [44,72]. Kumar et al. [45] showed that solids decreased biomass washout by trapping microbial communities inside the pores. Sequestration into the solid surface further allows to slow down the diffusion of exoenzymes and hydrolyzates away from the cell, thus saving substrates for anaerobic fermentation and methane production.

The surface area of conductive materials is a major factor controlling acetotrophic methanogens. For instance, methanogenic archaea belonging to Methanosarcina occurred at much higher abundance in powdered biochar amendments than in granulated biochar amendments [147]. Surface roughness and surface free energy of solid materials also controlled the activity of fixed cells [3]. Microorganisms tended to adhere better to roughest surfaces with a higher specific surface area to form biofilms. Materials having low surface free energy were more easily colonized by methanogens [30].

Granular activated carbon is widely used in anaerobic systems to improve fermentation. This has been partly attributed to the large granular activated carbon surface area that promotes microorganism attachment $[78,113]$. Here, the rapid degradation of VFAs provided ample feeding substrate for methanogenic archaea, and was explained by the formation of biofilms on granular activated carbon surfaces [12]. Comparison of granular activated carbon and powdered activated carbon showed that VFAs were better metabolized using the powder, thus suggesting that a highly porous structure allowed better colonization. It was also observed that acetate adsorbed on granular activated carbon is more available to methanogenic archaea [34].

The improvement of anaerobic digestion by biochar addition was attributed to selective colonization of functional microorganisms [31]. Biochar also facilitated biofilm formation on the surface and inside the pore channel, thus immobilizing microbes [69]. Porous biochar was also found to absorb ammonia, thus decreasing microbial inhibition by ammonia and fixing methanogens $[66,69]$. The microbial contact distance decreased in systems where magnetic carbon hosts microorganisms that are able to generate acetate and methane [81]. Carbon fibers were also used as supporting media for microbial growth in anaerobic fermentation systems. Biofilms easily formed on carbon fibers surfaces, thus increasing biomass retention time, which in turn improved of anaerobic digestion. Consequently, the methanogens population was more abundant in the biofilm fraction that developed on the packed bed than that in the liquid fraction [95]. The abundant genera in carbon fibers-amended bioreactors were acetoclastic Methanosaeta and Methanosarcina, suggesting that the enhancement of methanogenesis is explained partly by microbial immobilization.

\section{2. $p H$ buffering capacity}

In practice, anaerobic digestion of easy-acidified substrates always displayed low stability, VFAs conversion and methane production [107]. $\mathrm{CO}_{2}$ absorption and carbonation can improve anaerobic digestion, in particular the growth and activity of methanogenic archaea [90]. Biological and abiotic changes maintain the system stability. For instance, carbonation of $\mathrm{CO}_{2}$ by microbial carbonic anhydrase reduced the $\mathrm{CO}_{2}$ concentration $[115,118,117]$. Adding conductive carbon-based 
materials is beneficial on several grounds. For instance, biochar is an acid-buffering material by nature $[107,152]$. The $\mathrm{pH}$ was in the range of 4.0-3.0 with acetate as substrate for the control. By comparison, vermicompost biochar maintained it from 9.0 to 5.0. Biochar $\mathrm{pH}$ and pyrolytic temperature are positively correlated [43], suggesting that biochar can be used to correct an acidified or alkaline system depending on the pyrolytic temperature. Furthermore, the high pyrolytic temperature promoted the contribution of inorganic carbonate to alkalinity, whereas organic anions were the dominant contributors to the alkalinity for biochar produced at lower temperatures [140].

The release of alkali and alkaline earth cations from biochar was found to maintain the alkalinity of anaerobic digestion, suggesting that biochar can also be used as lime fertilizer in agriculture [28]. The pH value was about 5.2 when mineral fertilizer was used. The addition of biochar can enhance it to and even over 10.0. A practical soil management to improve soil quality by applying mineral organic fertilizer seemed to paly similar role [123], with obvious $\mathrm{pH}$ increase from 6.5 to 7.5. Conductive carbon cloth also showed the ability to resist acidity when the pH was adjusted to 5.0 and 7.0 [146]. Thus pH buffering capability contributes to feasible anaerobic digestion.

\subsection{Providing metal ions}

Biochar with high calcium, magnesium and iron provides essential elements for fermentative bacteria and methanogenic archaea [17,134]. Indeed, methanogenic archaea require more trace elements such as $\mathrm{Fe}$, $\mathrm{Cu}, \mathrm{Ni}$ and $\mathrm{Co}$, than fermentative bacteria [55]. These trace elements are important cofactors of enzymes controlling the acetoclastic methanogenic pathway [33]. Therefore, the impact of metal ion limitation on methanogens may be higher than that of bacteria. Specially, acetotrophic methanogens and acetate oxidizing bacteria directly compete for acetate, which is the most important anaerobic fermentation product. Trace elements, however, may be inhibitory and even toxic to anaerobic digestion, where the extent depended on concentration of these elements [70]. The concentration of trace metals during anaerobic digestion should be monitored under retention time to guarantee the efficiency of methane formation. A study showed that biochar increased the concentrations and ionization of aqueous $\mathrm{Co}$ and $\mathrm{Ni}$, which were thus more easily taken up by methanogenic archaea [97]. Kato et al. [41] observed a marked increase in methane production from ethanol when magnetite was supplied at $20 \mathrm{mM} \mathrm{Fe}$, compared to the control without addition of iron. The authors proposed that the leaching of iron ions and their contribution as a nutrient to enhance methanogenesis was insignificant due to low concentration of Fe (II), below $2 \mathrm{mM}$, in cultures. However, as iron is the active site of the enzyme, $2 \mathrm{mM}$ iron ion is sufficient to play a vital role $[144,145]$. Further comprehensive research to determine the optimum concentration of metal ions and their impact on microbial activity in anaerobic digestion is required.

\subsection{Reducing toxicity}

Ammonium ion $\left(\mathrm{NH}_{4}{ }^{+}\right)$and free ammonia $\left(\mathrm{NH}_{3}\right)$ are known to inhibit methanogenesis in anaerobic environments [127,137]. To circumvent the ammonia toxicity, diverse natural and synthetic materials have been extensively tested as absorbents to decrease toxicity. For instance metal oxides such as $\mathrm{Fe}_{2} \mathrm{O}_{3}, \mathrm{CaO}$ and $\mathrm{MgO}$ adsorb $\mathrm{NH}_{4}{ }^{+}-\mathrm{N}$, thus lowering leaching and diffuse pollution. Biochar is also used as an effective adsorbent for in situ removal. Biochar can also adsorb organics, phosphate, nitrate, nitrite, metals and $\mathrm{CO}_{2}[8,23]$. Biochar was also found to alleviate acid and ammonium stress, which in turn favored colonization by Methanosaeta and Methanosarcina [66]. Coconut coir and charcoal reduced the total ammonia nitrogen in bioreactors by harboring the denitrifying and ammonia oxidizing microorganisms with the methanogens [1]. Sasaki et al. [89] found that carbon fiber textiles stabilized thermophilic methanogenic bioreactors at elevated concentrations of ammonia nitrogen of $3 \mathrm{~g} / \mathrm{L}$. Carbon fibers also favored the colonisation of Methanosarcina sp.

Granular activated carbon of large surface area was reported to promote adsorption of toxic chemicals such as organic solvents and heavy metals [2]. Application of granular activated carbon was reported to both absorb phenolic compounds and increase methane production [11]. Magnetite and carbon nanotubes enriched phenol-degrading bacteria such as Syntrophorhabdus and Brooklawnia, and acetoclastic methanogens Methanosaeta, suggesting that Syntrophus and Methanosaeta were the species involved in methanogenic phenol degradation [133]. Conductive materials also enhance the resistance to sulfate stress in anaerobic fermentation. For example, adding $\mathrm{Fe}_{3} \mathrm{O}_{4}$ alleviated sulfate toxicity during mesophilic methanogenesis [61].

With the presence of large particles of conductive material, these heavy metals can be adsorbed on the surface of conductive materials. The immobilization of heavy metals significantly reduces the heavy metal ions in the solution, thus reducing the influence on microorganisms of the fermentation system $[82,98]$. Similarly, conductive materials can improve heavy metal passivation during anaerobic digestion of organic matter. For example, Wang et al. [111] showed that biochar improved heavy metal passivation during wet anaerobic digestion of pig manure. Applicaiton of biochar is also a green remediation strategy for heavy metal contaminated soil [112].

\subsection{Regulation of oxidation-reduction potential}

Humic substances can act as shuttles between Geobacter and other species $[40,93]$. In particular, humic substances stimulated interspecies electron transfer between Geobacter and Methanosarcina species in rice paddy soils [148]. By contrast, some studies of anaerobic digesters demonstrated that humic substances were not able to promote syntrophy between bacteria and methanogens $[6,20]$. Specially, the 2,6anthraquinone disulphonate (AQDS) analog of humic substances did not mediate electron transfer between $G$. metallireducens and $M$. barkeri in co-culture [58]. In addition to mediating electron transfer, the electron donating capacity of conductive materials such as humic substances should be considered. Few studies have monitored the oxidation-reduction potential during methanogenesis. Results showed that addition of conductive materials benefited methanogenesis at the final oxidation-reduction potential ranging from $-200 \mathrm{mV}$ to $-400 \mathrm{mV}$ [32]. Addition of diverse biochar was tested on methanogenesis in anaerobic digestion revealed no correlation between biochar conductivity and methanogenic capacity [102]. Authors concluded that the electron donating capacity was more essential. Yuan et al. [139] showed that biochar promotion of methanogenesis depends mainly on redox properties and charge-discharge capacity, rather than conductivity.

Salvador et al. [88] found that high concentrations of carbon nanotubes, of $5 \mathrm{~g} / \mathrm{L}$, decreased the oxydo-reduction potential of the anaerobic system, which in turn benefited methanogenesis. Beckmann et al. [10] proposed that neutral red in soluble form served both as electron donor and acceptor in the membrane-bound respiratory chain of Methanosarcina mazei. Neutral red was reduced when an excess hydrogen was the electron donor, but oxidized when CoB-S-S-CoM heterodisulfide was the electron acceptor. Overall the oxydoreduction potential can be modified sometimes by conductive materials, but molecular mechanisms remain unclear.

\section{Conclusion and perspective}

The production of biomethane in anaerobic digestor is actually explained by several main mechanisms: hydrogenetrophic methanogenesis, DIET-based $\mathrm{CO}_{2}$ reduction and acetoclastic methanogenesis. Massive research papers and reviews focused on DIET-based $\mathrm{CO}_{2}$ reduction, but acetoclastic methanogenesis deserves more attention. Conductive materials accelerate methane generation, yet underlying mechanisms are not fully deciphered. More than DIET, benefits to acetotrophic methanogens and acetoclastic methanogenesis and the 


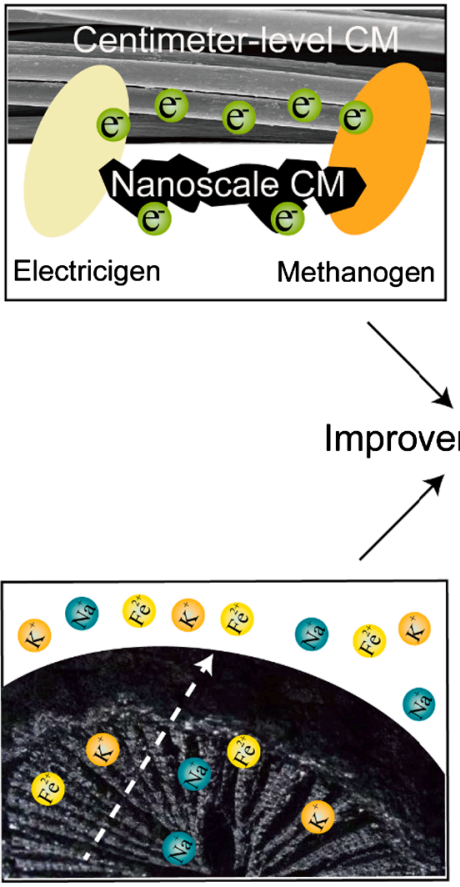

Providing metal ions
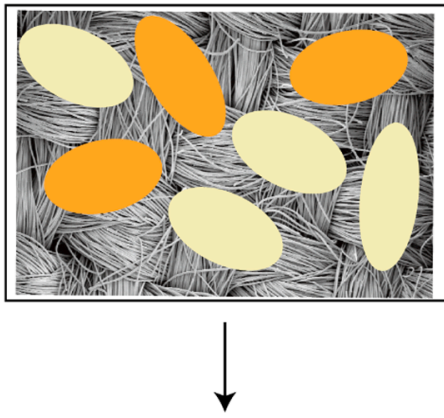

ophic methanogens activity

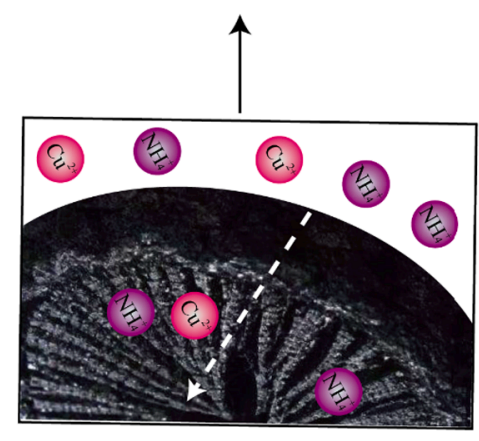

Reducing toxicity

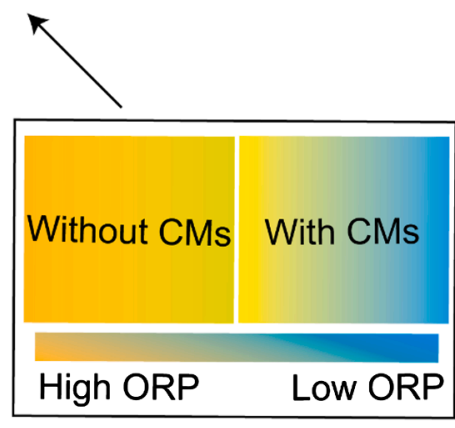

Regulating redox potential

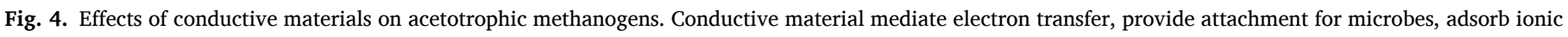
nutrients, regulate $\mathrm{pH}$ and oxydoreduction potential (ORP), and reduce toxicity.

responding mechanism mediated by conductive materials should also be taken seriously. Some rules of conductive materials' impact on anaerobic digestion are summarized as follows:

Different types of conductive materials or even different dozes of the same type have discrepant influences on the anaerobic digestion process, the methane-production capacity, and the related microbial community.

Besides the type of conductive materials, the duration of action and operation temperature altogether are considered to be the key factors affecting the effects of conductive materials on anaerobic digestion and methane production.

The long-term effects reserve more attention. Short-term experiments may be difficult to accurately reflect the potential effects of conductive materials on complex microbial consortia due to the lack of microbial adaptation. By comparison, long-term observation and comprehensive analysis are to be given topmost priority.

As a non-culture-based method, metagenomics becomes a vital tool to comprehend microbial communities sufficiently. Various omics techniques are more and more applied in understanding the effect of conductive materials on microbial communities. For example, metagenomics can be applied in identifying potential functional microbes. Furthermore, metatranscriptome is an alternative tool to identify microbial mechanism. Consequently, the application of omics methods will bring revolutionary improvements to the study of anaerobic digestion and methanogenic performance affected by conductive materials. In particular, omics can discover true functional microorganisms and related metabolic pathways. Collectively, the further research needs for comprehending the interactions between the conductive materials, substrate and intermediate metabolite, functional microorganisms, and the real impacts of adopting these additives on full-scale operations.

\section{CRediT authorship contribution statement}

Leilei Xiao: Data curation, Validation, Supervision. Eric Lichtfouse: Conceptualization, Data curation, Resources. P. Senthil Kumar: Conceptualization, Methodology, Validation, Supervision.

\section{Declaration of Competing Interest}

The authors declare that they have no known competing financial interests or personal relationships that could have appeared to influence the work reported in this paper.

\section{Acknowledgments}

This research was financially supported by the National Natural Science Foundation of China (no. 42077025, 51888103) and Youth Innovation Promotion Association, CAS (2021213).

\section{References}

[1] Acharya BK, Mohana S, Madamwar D. Anaerobic treatment of distillery spent wash - A study on upflow anaerobic fixed film bioreactor. Bioresour Technol 2008;99(11):4621-6.

[2] Ahmed E, Rothenberger A. Adsorption of volatile hydrocarbons in iron polysulfide chalcogels. Microporous Mesoporous Mater 2014;199:74-82.

[3] Ammar Y, Swailes D, Bridgens B, Chen JJ. Influence of surface roughness on the initial formation of biofilm. Surf Coat Technol 2015;284:410-6.

[4] Angel R, Claus P, Conrad R. Methanogenic archaea are globally ubiquitous in aerated soils and become active under wet anoxic conditions. ISME J 2012;6(4): $847-62$.

[5] Arif S, Liaquat R, Adil M. Applications of materials as additives in anaerobic digestion technology. Renew Sust Energ Rev 2018;97:354-66.

[6] Azman S, Khadem AF, Plugge CM, Stams AJM, Bec S, Zeeman G. Effect of humic acid on anaerobic digestion of cellulose and xylan in completely stirred tank reactors: inhibitory effect, mitigation of the inhibition and the dynamics of the microbial communities. Appl Microbiol Biotechnol 2017;101(2):889-901. 
[7] Baek G, Kim J, Cho K, Bae H, Lee C. The biostimulation of anaerobic digestion with (semi)conductive ferric oxides: their potential for enhanced biomethanation. Appl Microbiol Biotechnol 2015;99(23):10355-66.

[8] Bagreev A, Bandosz TJ, Locke DC. Pore structure and surface chemistry of adsorbents obtained by pyrolysis of sewage sludge-derived fertilizer. Carbon 2001;39(13):1971-9.

[9] Barua S, Zakaria BS, Dhar BR. Enhanced methanogenic co-degradation of propionate and butyrate by anaerobic microbiome enriched on conductive carbon fibers. Bioresour Technol 2018;266:259-66.

[10] Beckmann S, Welte C, Li XM, Oo YM, Kroeninger L, Heo Y, et al. Novel phenazine crystals enable direct electron transfer to methanogens in anaerobic digestion by redox potential modulation. Energy Environ Sci 2016;9(2):644-55.

[11] Bertin L, Lampis S, Todaro D, Scoma A, Vallini G, Marchetti L, et al. Anaerobic acidogenic digestion of olive mill wastewaters in biofilm reactors packed with ceramic filters or granular activated carbon. Water Res 2010;44(15):4537-49.

[12] Capson-Tojo G, Moscoviz R, Ruiz D, Santa-Catalina G, Trably E, Rouez M, et al Addition of granular activated carbon and trace elements to favor volatile fatty acid consumption during anaerobic digestion of food waste. Bioresour Technol 2018;260:157-68.

[13] Cavalcante WA, Gehring TA, Zaiat M. Stimulation and inhibition of direct interspecies electron transfer mechanisms within methanogenic reactors by adding magnetite and granular active carbon. Chem Eng J 2021;415:128882.

[14] Chauhan A, Ogram A. Phylogeny of acetate-utilizing microorganisms in soils along a nutrient gradient in the Florida everglades. Appl Environ Microbiol 2006 72(10):6837-40.

[15] Chen SS, Rotaru AE, Liu FH, Philips J, Woodard TL, Nevin KP, et al. Carbon cloth stimulates direct interspecies electron transfer in syntrophic co-cultures. Bioresour Technol 2014;173:82-6.

[16] Chen SS, Rotaru AE, Shrestha PM, Malvankar NS, Liu FH, Fan W, et al: Promoting interspecies electron transfer with biochar. Sci Rep 2014;4:5019.

[17] Chen Y, Cheng JJ, Creamer KS. Inhibition of anaerobic digestion process: a review. Bioresour Technol 2008;99(10):4044-64.

[18] Conrad R. Quantification of methanogenic pathways using stable carbon isotopic signatures: a review and a proposal. Org Geochem 2005;36(5):739-52.

[19] Dang Y, Holmes DE, Zhao ZQ, Woodard TL, Zhang YB, Sun DZ, et al. Enhancing anaerobic digestion of complex organic waste with carbon-based conductive materials. Bioresour Technol 2016;220:516-22.

[20] Dang Y, Lei YQ, Liu Z, Xue YT, Sun DZ, Wang LY, et al. Impact of fulvic acids on bio-methanogenic treatment of municipal solid waste incineration leachate. Water Res 2016;106:71-8.

[21] Evans PN, Boyd JA, Leu AO, Woodcroft B, Parks DH, Hugenholtz P, et al. An evolving view of methane metabolism in the archaea. Nat Rev Microbiol 2019;17 (4):219-32.

[22] Evans PN, Parks DH, Chadwick GL, Robbins SJ, Orphan VJ, Golding SD, et al. Methane metabolism in the archaeal phylum bathyarchaeota revealed by genome-centric metagenomics. Science 2015;350(6259):434-8.

[23] Fagbohungbe MO, Herbert BMJ, Hurst L, Li H, Usmani SQ, Semple KT. Impac of biochar on the anaerobic digestion of citrus peel waste. Bioresour Technol 2016; 216:142-9.

[24] Feng H, Guo J, Han M, Wang W, Peng C, Jin J, Song X, Yu S. A review of the mechanisms and controlling factors of methane dynamics in forest ecosystems. Forest Ecol Manag 2020;455:117702.

[25] Fey A, Conrad R. Effect of temperature on carbon and electron flow and on the archaeal community in methanogenic rice field soil. Appl Environ Microbiol 2000;66(11):4790-7.

[26] Fu L, Zhou T, Wang JY, You LX, Lu YH, Yu LP, et al. NanoFe3O4 as solid electron shuttles to accelerate acetotrophic methanogenesis by methanosarcina barkeri. Front Microbiol 2019;10:388.

[27] Gao K, Lu Y. Putative extracellular electron transfer in methanogenic archaea. Front Microbiol 2021;12:611739.

[28] Glaser B, Wiedner K, Seelig S, Schmidt HP, Gerber H. Biochar organic fertilizers from natural resources as substitute for mineral fertilizers. Agron Sustainable Dev 2015;35(2):667-78.

[29] Guskos N, Papadopoulos GJ, Likodimos V, Patapis S, Yarmis D, Przepiera A, et al. Photoacoustic, epr and electrical conductivity investigations of three synthetic mineral pigments: hematite, goethite and magnetite. Mater Res Bull 2002;37(6): 1051-61.

[30] Habouzit F, Gevaudan G, Hamelin J, Steyer JP, Bernet N. Influence of support material properties on the potential selection of Archaea during initial adhesion of a methanogenic consortium. Bioresour Technol 2011;102(5):4054-60.

[31] He PJ, Zhang HH, Duan HW, Shao LM, Lu F. Continuity of biochar-associated biofilm in anaerobic digestion. Chem Eng J 2020;390:124605.

[32] Hirano S, Matsumoto N, Morita M, Sasaki K, Ohmura N. Electrochemical control of redox potential affects methanogenesis of the hydrogenotrophic methanogen methanothermobacter thermautotrophicus. Lett Appl Microbiol 2013;56(5): 315-21.

[33] Hoelzle RD, Virdis B, Batstone DJ. Regulation mechanisms in mixed and pure culture microbial fermentation. Biotechnol Bioeng 2014;111(11):2139-54.

[34] Holmes DE, Smith JA. Biologically produced methane as a renewable energy source. Adv Appl Microbiol 2016;97:1-61.

[35] Inaba R, Nagoya M, Kouzuma A, Watanabe K. Metatranscriptomic evidence for magnetite nanoparticle-stimulated acetoclastic methanogenesis under continuous agitation. Appl Environ Microbiol 2019;85(23):e01733-01719.

[36] Jetten MSM, Stams AJM, Zehnder AJB. Methanogenesis from acetate - a comparison of the acetate metabolism in methanothrix-soehngenii and methanosarcina spp. FEMS Microbiol Lett 1992;88(3-4):181-97.
[37] Jiang Q, Chen Y, Yu S, Zhu R, Zhong C, Zou H, et al. Effects of citrus peel biochar on anaerobic co-digestion of food waste and sewage sludge and its direct interspecies electron transfer pathway study. Chem Eng J 2020;398:125643.

[38] Jing YH, Wan JJ, Angelidaki I, Zhang SC, Luo G. Itraq quantitative proteomic analysis reveals the pathways for methanation of propionate facilitated by magnetite. Water Res 2017;108:212-21.

[39] Kang HJ, Lee SH, Lim TG, Lim TG, Park JH, Park HD. Recent advances in methanogenesis through direct interspecies electron transfer via conductive materials: a molecular microbiological perspective. Bioresour Technol 2021;322: 124587.

[40] Kappler A, Benz M, Schink B, Brune A. Electron shuttling via humic acids in microbial iron(III) reduction in a freshwater sediment. FEMS Microbiol Ecol 2004;47(1):85-92

[41] Kato S, Hashimoto K, Watanabe K. Methanogenesis facilitated by electric syntrophy via (semi)conductive iron-oxide minerals. Environ Microbiol 2012;14 (7):1646-54.

[42] Kato S, Igarashi K. Enhancement of methanogenesis by electric syntrophy with biogenic iron-sulfide minerals. Microbiologyopen 2019;8(3):e00647.

[43] Komnitsas K, Zaharaki D, Pyliotis I, Vamvuka D, Bartzas G. Assessment of pistachio shell biochar quality and its potential for adsorption of heavy metals. Waste Biomass Valorization 2015;6(5):805-16.

[44] Kubota M, Nakabayashi T, Matsumoto Y, Shiomi T, Yamada Y, Ino K, et al. Selective adsorption of bacterial cells onto zeolites. Colloid Surface B 2008;64(1): 88-97.

[45] Kumar G, Sivagurunathan P, Sen B, Kim SH, Lin CY. Mesophilic continuous fermentative hydrogen production from acid pretreated de-oiled jatropha waste hydrolysate using immobilized microorganisms. Bioresour Technol 2017;240: $137-43$.

[46] Lee J, Koo T, Yulisa A, Hwang S. Magnetite as an enhancer in methanogenic degradation of volatile fatty acids under ammonia-stressed condition. J Environ Manage 2019;241:418-26.

[47] Lee S, Kang H, Lim T, Park H. Magnetite and granular activated carbon improve methanogenesis via different metabolic routes. Fuel 2020;281:118768.

[48] Lei YQ, Sun DZ, Dang Y, Chen HM, Zhao ZQ, Zhang YB, et al. Stimulation of methanogenesis in anaerobic digesters treating leachate from a municipal solid waste incineration plant with carbon cloth. Bioresour Technol 2016;222:270-6.

[49] Lei YQ, Wei LX, Liu TY, Xiao YY, Dang Y, Sun DZ, et al. Magnetite enhances anaerobic digestion and methanogenesis of fresh leachate from a municipal solid waste incineration plant. Chem Eng J 2018;348:992-9.

[50] Li C, Lesnik KL, Liu H. Stay connected: electrical conductivity of microbial aggregates. Biotechnol Adv 2017;35(6):669-80.

[51] Li HJ, Chang JL, Liu PF, Fu L, Ding DW, Lu YH. Direct interspecies electron transfer accelerates syntrophic oxidation of butyrate in paddy soil enrichments Environ Microbiol 2015;17(5):1533-47.

[52] Li JJ, Xiao LL, Zheng SL, Zhang YC, Luoc M, Tong C, et al. A new insight into the strategy for methane production affected by conductive carbon cloth in wetland soil: beneficial to acetoclastic methanogenesis instead of $\mathrm{CO}_{2}$ reduction. Sci Total Environ 2018;643:1024-30.

[53] Li Q, Xu MJ, Wang GJ, Chen R, Qiao W, Wang XC. Biochar assisted thermophilic co-digestion of food waste and waste activated sludge under high feedstock to seed sludge ratio in batch experiment. Bioresour Technol 2018;249:1009-16.

[54] Li X, Li Q, He J, Zhang YF, Zhu NM. Application of activated carbon to enhance biogas production rate of Flammulina velutipes residues with composting pretreatment. Waste Biomass Valorization 2020:280-96.

[55] Li Y, Chen YG, Wu J. Enhancement of methane production in anaerobic digestion process: a review. Appl Energy 2019;240:120-37.

[57] Lim E, Tian H, Chen Y, Ni K, Zhang J, Tong Y. Methanogenic pathway and microbial succession during start-up and stabilization of thermophilic food waste anaerobic digestion with biochar. Bioresour Technol 2020;314:123751.

[58] Liu FH, Rotaru AE, Shrestha PM, Malvankar NS, Nevin KP, Lovley DR. Promoting direct interspecies electron transfer with activated carbon. Energy Environ Sci 2012;5(10):8982-9.

[59] Liu FH, Rotaru AE, Shrestha PM, Malvankar NS, Nevin KP, Lovley DR. Magnetite compensates for the lack of a pilin-associated c-type cytochrome in extracellular electron exchange. Environ Microbiol 2015;17(3):648-55.

[60] Liu J, Liu F, Yu J, Wang Q, Li Z, Liu K, et al. Proteomics reveal biomethane production process induced by carbon nanotube. Environ Res 2021;200:111417.

61] Liu Y, Gu MQ Yin QD, Wu GX. Inhibition mitigation and ecological mechanism of mesophilic methanogenesis triggered by supplement of ferroferric oxide in sulfate-containing systems. Bioresour Technol 2019;288:121546.

[62] Liu YC, Whitman WB. Metabolic, phylogenetic, and ecological diversity of the methanogenic archaea. Incredible Anaerobes From Physiol Genom Fuels 2008; 1125:171-89.

[63] Lovley DR. Happy together: microbial communities that hook up to swap electrons. ISME J 2017:11(2):327-36.

[64] Lovley DR. Syntrophy goes electric: direct interspecies electron transfer. Annu Rev Microbiol 2017;71:643-64.

[65] Lu C, Shen Y, Li C, Zhu N, Yuan H. redox-active biochar and conductive graphite stimulated methanogenic metabolism in anaerobic digestion of waste-activated sludge: beyond direct interspecies electron transfer. ACS Sustainable Chem Eng 2020;8:12626-36.

[66] Lu F, Luo CH, Shao LM, He PJ. Biochar alleviates combined stress of ammonium and acids by firstly enriching Methanosaeta and then Methanosarcina. Water Res 2016;90:34-43. 
[67] Lu JH, Chen C, Huang C, Zhuang HC, Leu SY, Lee DJ. Dark fermentation production of volatile fatty acids from glucose with biochar amended biological consortium. Bioresour Technol 2020;303:122921.

[68] Lu JS, Chang JS, Lee DJ. Adding carbon-based materials on anaerobic digestion performance: a mini-review. Bioresour Technol 2020;300:122696.

[69] Luo CH, Lu F, Shao LM, He PJ. Application of eco-compatible biochar in anaerobic digestion to relieve acid stress and promote the selective colonization of functional microbes. Water Res 2015;70:496.

[70] A.N. Matheri M. Belaid T. Seodigeng J. Ngila The Role of Trace Elements on Anaerobic Co-digestion in Biogas Production 2016 London, U.K.

[71] Martins G, Salvador AF, Pereira L, Alves MM. Methane production and conductive materials: a critical review. Environ Sci Technol 2018;52(18):10241-53.

[72] Masebinu SO, Akinlabi ET, Muzenda E, Aboyade AO. A review of biochat properties and their roles in mitigating challenges with anaerobic digestion. Renew Sust Energ Rev 2019;103:291-307.

[73] Mei R, Nobu MK, Narihiro T, Yu J, Sathyagal A, Willman E, et al. Novel Geobacter species and diverse methanogens contribute to enhanced methane production in media-added methanogenic reactors. Water Res 2018;147:403-12.

[74] Pan JT, Ma JY, Zhai LM, Liu HB. Enhanced methane production and syntrophic connection between microorganisms during semi-continuous anaerobic digestion of chicken manure by adding biochar. J Cleaner Prod 2019;240:118178.

[75] Pan P, Hong B, Mbadinga SM, Wang LY, Liu JF, Yang SZ, et al. Iron oxides alter methanogenic pathways of acetate in production water of high-temperature petroleum reservoir. Appl Microbiol Biot 2017;101(18):7053-63.

[76] Paton M, Rodriguez J. A compilation and bioenergetic evaluation of syntrophic microbial growth yields in anaerobic digestion. Water Res 2019;159:176-83.

[77] Peng H, Zhang YB, Tan DM, Zhao ZQ, Zhao HM, Quan X. Roles of magnetite and granular activated carbon in improvement of anaerobic sludge digestion. Bioresour Technol 2018;249:666-72.

[78] Pham TH, Aelterman P, Verstraete W. Bioanode performance in bioelectrochemical systems: recent improvements and prospects. Trends Biotechnol 2009;27(3):168-78.

[79] Prabhu AV, Raja SA, Avinash A, Pugazhendhi A. Parametric optimization of biogas potential in anaerobic co-digestion of biomass wastes. Fuel 2021;288: 119574.

[80] Putkinen A, Siljanen H, Laihonen A, Paasisalo I, Porkka K, Tiirola M, et al. insight to the role of microbes in the methane exchange in trees: evidence from metagenomic sequencing. New Phytol 2021. https://doi.org/10.1111/ nph.17365.

[81] Qin Y, Wang HS, Li XR, Cheng JJ, Wu WX. Improving methane yield from organic fraction of municipal solid waste (ofmsw) with magnetic rice-straw biochar. Bioresour Technol 2017;245:1058-66.

[82] Qiu B, Tao X, Wang H, Li W, Chu H. Biochar as a low-cost adsorbent for aqueous heavy metal removal: a review. J Anal Appl Pyrol 2021;11:105081.

[83] Qiu CP, Feng YZ, Wu M, Zhang JW, Chen XF, Li ZP. NanoFe $\mathrm{O}_{4}$ accelerates methanogenic straw degradation in paddy soil enrichments. Appl Soil Ecol 2019 144:155-64.

[84] Qiu L, Deng YF, Wang F, Davaritouchaee M, Yao YQ. A review on biocharmediated anaerobic digestion with enhanced methane recovery. Renew Sust Energ Rev 2019;115:109373.

[85] Ren GP, Chen P, Yu J, Liu JB, Ye J, Zhou S. Recyclable magnetite-enhanced electromethanogenesis for biomethane production from wastewater. Water Res 2019;166:115095.

[86] Rotaru AE, Shrestha PM, Liu FH, Shrestha M, Shrestha D, Embree M, et al. A new model for electron flow during anaerobic digestion: direct interspecies electron transfer to Methanosaeta for the reduction of carbon dioxide to methane. Energy Environ Sci 2014;7(1):408-15.

[87] Ryue J, Lin L, Liu Y, Lu WJ, McCartney D, Dhar BR. Comparative effects of gac addition on methane productivity and microbial community in mesophilic and thermophilic anaerobic digestion of food waste. Biochem Eng J 2019;146:79-87.

[88] Salvador AF, Martins G, Melle-Franco M, Serpa R, Stams AJM, Cavaleiro AJ, et al. Carbon nanotubes accelerate methane production in pure cultures of methanogens and in a syntrophic coculture. Environ Microbiol 2017;19(7); 2727-39.

[89] Sasaki K, Morita M, Hirano S, Ohmura N, Igarashi Y. Decreasing ammonia inhibition in thermophilic methanogenic bioreactors using carbon fiber textiles. Appl Microbiol Biot 2011;90(4):1555-61.

[90] Shen YW, Linville JL, Urgun-Demirtas M, Schoene RP, Snyder SW. Producing pipeline-quality biomethane via anaerobic digestion of sludge amended with corn stover biochar with in-situ $\mathrm{CO}_{2}$ removal. Appl Energy 2015;158:300-9.

[91] Shrestha PM, Malvankar NS, Werner JJ, Franks AE, Elena-Rotaru A, Shrestha M, et al. Correlation between microbial community and granule conductivity in anaerobic bioreactors for brewery wastewater treatment. Bioresour Technol 2014;174:306-10.

[92] Stams AJM, Plugge CM. Electron transfer in syntrophic communities of anaerobic bacteria and archaea. Nat Rev Microbiol 2009;7(8):568-77.

[93] Stern N, Mejia J, He SM, Yang Y, Ginder-Vogel M, Roden EE. Dual Role of Humic Substances As Electron Donor and Shuttle for dissimilatory iron reduction. Environ Sci Technol 2018;52(10):5691-9.

[94] Tang J, Zhuang L, Ma JL, Tang ZY, Yu Z, Zhou SG. Secondary mineralization of ferrihydrite affects microbial methanogenesis in geobacter-methanosarcina cocultures. Appl Environ Microbiol 2016;82(19):5869-77.

[95] Tatara M, Makiuchi T, Ueno Y, Goto M, Sode K. Methanogenesis from acetate and propionate by thermophilic down-flow anaerobic packed-bed reactor. Bioresour Technol 2008;99(11):4786-95.

[96] Tena M, Perez M, Solera R. Effect of hydraulic retention time on the methanogenic step of a two-stage anaerobic digestion system from sewage sludge and wine vinasse: microbial and kinetic evaluation - sciencedirect. Fuel 2021;296. https://doi.org/10.1016/j.fuel.2021.120674.

[97] Thanh PM, Ketheesan B, Yan Z, Stuckey DC. Trace metal speciation and bioavailability in anaerobic digestion: a review. Biotechnol Adv 2016;34(2): $122-36$.

[98] Tuomikoski, S., Runtti, H., Romar, H., Lassi, U., Kangas, T., 2021, Multiple heavy metals removal simultaneously by a biomass-based porous carbon. Water Environ. Res. https://doi.org/10.1002/wer.1514.

[99] Usman M, Hao SL, Chen HH, Ren S, Tsang DCW, O-Thong, Luo G, Zhang SC. Molecular and microbial insights towards understanding the anaerobic digestion of the wastewater from hydrothermal liquefaction of sewage sludge facilitated by granular activated carbon (gac). Environ Int 2019;133:105257.

[100] Valadbeigi Y. Comparison of effects of charge delocalization and $\pi$-electron delocalization on the stability of monocyclic compounds. J Mol Graph Model 2018:104-12.

[101] Van Steendam C, Smets I, Skerlos S, Raskin L. Improving anaerobic digestion via direct interspecies electron transfer requires development of suitable characterization methods. Curr Opin Biotechnol 2019;57:183-90.

[102] Viggi CC, Simonetti S, Palma E, Pagliaccia P, Braguglia C, Fazi S, et al. Enhancing methane production from food waste fermentate using biochar: the added value of electrochemical testing in pre-selecting the most effective type of biochar. Biotechnol Biofuels 2017;10:303.

[103] Vollhardt P, Neil S. Organic chemistry: structure and function. 5th. New York: W. H. Freeman and Company; 2007.

[104] Wang C, Wang C, Liu J, Han Z, Zhu L. Role of magnetite in methanogenic degradation of different substances. Bioresour Technol 2020;314:123720.

[105] Wang CQ, Liu Y, Gao XY, Chen H, Xu XY, Zhu L. Role of biochar in the granulation of anaerobic sludge and improvement of electron transfer characteristics. Bioresour Technol 2018;268:28-35.

[106] Wang CQ, Qiao WL, Chen H, Xu XY, Zhu L. A short-term stimulation of ethanol enhances the effect of magnetite on anaerobic digestion. Appl Microbiol Biotechnol 2019;103(3):1511-22.

[107] Wang D, Ai J, Shen F, Yang G, Zhang YZ, Deng SH, et al. Improving anaerobic digestion of easy-acidification substrates by promoting buffering capacity using biochar derived from vermicompost. Bioresour Technol 2017;227:286-96.

[108] Wang DX, Han YX, Han HJ, Li K, Xu CY, Zhuang HF. New insights into enhanced anaerobic degradation of fischer-tropsch wastewater with the assistance of magnetite. Bioresour Technol 2018;257:147-56.

[110] Wang H, Byrne JM, Liu PF, Liu J, Dong XZ, Lu YH. Redox cycling of Fe(II) and Fe (III) in magnetite accelerates aceticlastic methanogenesis by Methanosarcina mazei. Environmental Microbiology Reports 2020;12(1):97-109.

[111] Wang J, Hao X, Liu Z, Guo Z, Zhu L, Xiong B, et al. Biochar improves heavy metal passivation during wet anaerobic digestion of pig manure. Environ Sci Pollut $R$ 2021;28:635-44.

[112] Wang L, Rinklebe J, Tack F, Hou D. A review of green remediation strategies for heavy metal contaminated soil. Soil Use and Manage 2021. https://doi.org/ 10.1111/sum.12717.

[113] Watanabe K. Recent developments in microbial fuel cell technologies for sustainable bioenergy. J Biosci Bioeng 2008;106(6):528-36.

[114] Welte C, Deppenmeier U. Bioenergetics and anaerobic respiratory chains of aceticlastic methanogens. Biochimica Biophysica Acta-Bioenerget 2014;1837(7): $1130-47$.

[115] Xiao LL, Hao JC, Wang WY, Lian B, Shang GD, Yang YW, et al. The up-regulation of carbonic anhydrase genes of Bacillus mucilaginosus under soluble $\mathrm{Ca}^{2}$ deficiency and the heterologously expressed enzyme promotes calcite dissolution. Geomicrobiol J 2014;31(7):632-41.

[116] Xiao L, Li J, Lichtfouse E, Li Z, Liu F. Augmentation of chloramphenicol degradation by Geobacter-based biocatalysis and electric field. J of Hazard Mater 2021:410:124977.

[117] Xiao LL, Lian B, Dong CL, Liu FH. The selective expression of carbonic anhydrase genes of aspergillus nidulans in response to changes in mineral nutrition and $\mathrm{CO}_{2}$ concentration. Microbiologyopen 2016;5(1):60-9.

[118] Xiao LL, Lian B, Hao JC, Liu CQ, Wang SJ. Effect of carbonic anhydrase on silicate weathering and carbonate formation at present day $\mathrm{CO}_{2}$ concentrations compared to primordial values. Sci Rep 2015;5:7733.

[119] Xiao L, Lichtfouse E, Kumar PS, Wang Q, Liu F. Biochar promotes methane production during anaerobic digestion of organic waste. Environ Chem Lett 2021. https://doi.org/10.1007/s10311-021-01251-6.

[120] Xiao L, Liu FH, Lichtfouse E, Zhang P, Feng DW, Li FB. Methane production by acetate dismutation stimulated by Shewanella oneidensis and carbon materials: an alternative to classical $\mathrm{CO}_{2}$ reduction. Chem Eng J 2020;389:124469.

[121] Xiao LL, Liu FH, Liu JC, Li JJ, Zhang YC, Yu JF, et al. Nano- $\mathrm{Fe}_{3} \mathrm{O}_{4}$ particles accelerating electromethanogenesis on an hour-long timescale in wetland soil. Environmental Science-Nano 2018;5(2):436-45.

[122] Xiao L, Liu FH, Xu HD, Feng DW, Liu JC, Han GX. Biochar promotes methane production at high acetate concentrations in anaerobic soils. Environ Chem Lett 2019;17(3):1347-52.

[123] Xiao L, Sun Q, Yuan H, Lian B. A practical soil management to improve soil quality by applying mineral organic fertilizer. Acta Geochim 2017;36:198-204.

[124] Xiao L, Sun R, Zhang P, Zheng SL, Tan Y, Li JJ, et al. Simultaneous intensification of direct acetate cleavage and $\mathrm{CO}_{2}$ reduction to generate methane by bioaugmentation and increased electron transfer. Chem Eng J 2019;378:122229. 
[125] Xiao LL, Wang YP, Lichtfouse E, Li ZK, Kumar S, Liu J, et al. Effect of antibiotics on the microbial efficiency of anaerobic digestion of wastewater: a review. Front Microbiol 2021;11:611613.

[126] Xiao L, Wei WC, Luo M, Xu HD, Feng DW, Yu JF, et al. A potential contribution of a Fe(III)-rich red clay horizon to methane release: biogenetic magnetite-mediated methanogenesis. Catena 2019;181:104081.

[127] Xiao LL, Xie BH, Liu JC, Zhang HX, Han GX, Wang OM, et al. Stimulation of longterm ammonium nitrogen deposition on methanogenesis by methanocellaceae in a coastal wetland. Sci Total Environ 2017;595:337-43.

[128] Xiao LL, Zheng SL, Lichtfouse E, Luo M, Tan Y, Liu FH. Carbon nanotubes accelerate acetoclastic methanogenesis from pure culture to anaerobic soil. Soil Biol Biochem 2020;150:107938.

[129] Xu H, Chang JL, Wang H, Liu YC, Zhang XY, Liang P, et al. Enhancing direct interspecies electron transfer in syntrophic-methanogenic associations with (semi)conductive iron oxides: Effects and mechanisms. Sci Total Environ 2019; 695:133876.

[130] Xu SY, He CQ, Luo LW, Lu F, He PJ, Cui LF. Comparing activated carbon of different particle sizes on enhancing methane generation in upflow anaerobic digester. Bioresour Technol 2015;196:606-12.

[131] Yamada C, Kato S, Ueno Y, Ishii M, Igarashi Y. Conductive iron oxides accelerate thermophilic methanogenesis from acetate and propionate. J Biosci Bioeng 2015 119(6):678-82.

[132] Yan WW, Shen N, Xiao YY, Chen Y, Sun FQ, Tyagi VK, et al. The role of conductive materials in the start-up period of thermophilic anaerobic system. Bioresour Technol 2017;239:336-44.

[133] Yan WW, Sun FQ, Liu JB, Zhou Y. Enhanced anaerobic phenol degradation by conductive materials via eps and microbial community alteration. Chem Eng J 2018;352:1-9.

[134] Yang G, Wang ZH, Xian QM, Shen F, Sun C, Zhang YZ, et al. Effects of pyrolysis temperature on the physicochemical properties of biochar derived from vermicompost and its potential use as an environmental amendment. RSC Adv 2015;5(50):40117-25.

[135] Yang PX, Tan GYA, Aslam M, Kim J, Lee PH. Metatranscriptomic evidence for classical and RuBisCO-mediated $\mathrm{CO}_{2}$ reduction to methane facilitated by direct interspecies electron transfer in a methanogenic system. Sci Rep 2019;9:4116.

[136] Yang ZM, Guo RB, Shi XS, Wang CS, Wang L, Dai M. Magnetite nanoparticles enable a rapid conversion of volatile fatty acids to methane. RSC Adv 2016;6(31): 25662-8.

[137] Yenigun O, Demirel B. Ammonia inhibition in anaerobic digestion: a review. Process Biochem 2013;48(5-6):901-11.

[138] Yin QD, He K, Liu AK, Wu GX. Enhanced system performance by dosing ferroferric oxide during the anaerobic treatment of tryptone-based high-strength wastewater. Appl Microbiol Biot 2017;101(9):3929-39.
[139] Yuan HY, Ding LJ, Zama EF, Liu PP, Hozzein WN, Zhu YG. Biochar modulates methanogenesis through electron syntrophy of microorganisms with ethanol as a substrate. Environ Sci Technol 2018;52(21):12198-207.

[140] Yuan JH, Xu RK, Zhang H. The forms of alkalis in the biochar produced from crop residues at different temperatures. Bioresour Technol 2011;102(3):3488-97.

[141] Zabranska J, Pokorna D. Bioconversion of carbon dioxide to methane using hydrogen and hydrogenotrophic methanogens. Biotechnol Adv 2018;36(3): 707-20.

[142] Zhang JX, Mao LW, Zhang L, Loh KC, Dai YJ, Tong YW. Metagenomic insight into the microbial networks and metabolic mechanism in anaerobic digesters for food waste by incorporating activated carbon. Sci Rep 2017;7:11293.

[143] Zhang MY, Ma YQ, Ji DD, Li XY, Zhang JS, Zang LH. Synergetic promotion of direct interspecies electron transfer for syntrophic metabolism of propionate and butyrate with graphite felt in anaerobic digestion. Bioresour Technol 2019;287: 121373.

[144] Zhang YC, Liu FH, Hao QQ, Xiao LL. Target-oriented recruitment of Clostridium to promote biohydrogen production by nano-ferrihydrite. Fuel 2020;276:118049.

[145] Zhang YC, Liu FH, Xu HD, Xiao LL. Extraction of electrons by magnetite and ferrihydrite from hydrogen-producing Clostridium bifermentans by strengthening the acetate production pathway. Sci China Technol Sc 2019;62(10):1719-25.

[146] Zhao ZQ, Zhang YB, Li Y, Dang Y, Zhu TT, Quan X. Potentially shifting from interspecies hydrogen transfer to direct interspecies electron transfer for syntrophic metabolism to resist acidic impact with conductive carbon cloth. Chem Eng J 2017;313:10-8.

[147] Zhou GW, Yang XR, Marshall CW, Li H, Zheng BX, Yan Y, et al. Biochar addition increases the rates of dissimilatory iron reduction and methanogenesis in ferrihydrite enrichments. Front Microbiol 2017;8:589.

[148] Zhou SG, Xu JL, Yang GQ, Zhuang L. Methanogenesis affected by the cooccurrence of iron(III) oxides and humic substances. FEMS Microbiol Ecol 2014; 88(1):107-20.

[149] Zhu H, Han YX, Ma WC, Han HJ, Ma WW, Xu CY. New insights into enhanced anaerobic degradation of coal gasification wastewater (cgw) with the assistance of graphene. Bioresour Technol 2018;262:302-9.

[150] Zhuang HF, Zhu H, Shan SD, Zhang LT, Fang CR, Shi Y. Potential enhancement of direct interspecies electron transfer for anaerobic degradation of coal gasification wastewater using up-flow anaerobic sludge blanket (uasb) with nitrogen doped sewage sludge carbon assisted. Bioresour Technol 2018;270:230-5.

[151] Zhuang L, Ma JL, Yu Z, Wang YQ, Tang J. Magnetite accelerates syntrophic acetate oxidation in methanogenic systems with high ammonia concentrations. Microb Biotechnol 2018;11(4):710-20.

[152] Xiao Leilei, Lichtfouse Eric, Kumar Senthil, Wang Quan, Liu Fanghua. Biochar promotes methane production during anaerobic digestion of organic waste. Environ Chem Lett 2021. https://doi.org/10.1007/s10311-021-01251-6. 